\title{
Ajalugu, mida polnud? Homoseksuaalse iha jäljed kolmes kohtuasjas ${ }^{1}$
}

\author{
Andreas Kalkun \\ Eesti Kirjandusmuuseumi Eesti Rahvaluule Arhiivi teadur \\ andreas.kalkun@folklore.ee
}

\begin{abstract}
Teesid: Eesti Vabariigi kriminaalseadustik, mis ei kriminaliseerinud täiskasvanute vahel mõlema poole nõusolekul toimunud homoseksuaalseid akte, võeti vastu 1929. aastal ning hakkas kehtima 1935. aasta alguses. Enne uue kriminaalseadustiku vastuvõtmist kehtis Eesti Vabariigis tsaariaegne nuhtlusseadustik, milles paragrahv 995 käsitles meestevahelist suguühet kui kuritegu. Vaatlen artiklis Eesti Vabariigi Sõjaväeringkonna kohtus aastatel 1919, 1929 ja 1931 arutatud kolme juhtumit, kus mehi süüdistati homoseksuaalsuses. Lisaks kohtuasjadele on minu käsitluse tähtsateks allikateks ka kaasaegses ajakirjanduses ilmunud homoseksuaalsust käsitlevad tekstid, mis lisavad konteksti ning aitavad diskursiivselt raamistada vaadeldavaid toimikuid. Analüüsin spetsiifilisi karistamise ja kontrolliga seotud kohtutoimikute tekste kui võimalikke queer-ajaloo allikaid.
\end{abstract}

Märksõnad: Eesti Vabariik, homoseksuaalsus, kohtuasjad, queer-ajalugu

Homoseksuaalsete meeste kohtuasjade uurimiseni jõudsin tänu kahele inspireerivale projektile. Esimene inspiratsiooniallikas oli 2015. aastal Veneetsia biennaalil ning aasta hiljem Tallinnas Okupatsioonide muuseumis eksponeeritud kunstnik Jaanus Samma näitus “NSFW. Esimehe lugu”. Kunstiprojekti üheks osaks oli lisaks esemetele, installatsioonidele, muusikale, fotodele ja videotele ühe kolhoosiesimehe inglise keelde tõlgitud ja anonümiseeritud kohtutoimik (Samma \& Viola 2015). Homoseksuaalsuse eest karistatud endise kolhoosiesimehe toimik oli väga inforikas ja samas tihedusele vaatamata hästi vastuoluline kultuurikirjeldus. Kohtutoimikust peegeldus selle inimese elu nii, et sellest olid mingid kummalised ja intiimsed detailid välja valgustatud, kuid palju olulist ja olemuslikku jäi küsimärgina õhku rippuma. Kunstnikule inspiratsiooniks olnud homoseksuaalse mehe kohtuasi tekitas tunde, et sellised väärtuslikud allikad vajaksid peale subtiilsete kunstiliste käsitluste ka kultuuriuurija või lihtsalt marginaalsete lugude ja inimeste uurija - näiteks folkloristi - analüüsi. On ju selge, et sellistes toimikutes leiduv info on Eesti 
queer-ajaloo ${ }^{2}$ seisukohast ainulaadne ja tähtis allikas ning vajame teadmisi selliste allikate olemuse ja sisu kohta.

Teine mõjuv inspiratsiooniallikas pärineb Soomest. 2016. aastal ilmus ajaloolase Sandra Hagmani raamat "Seitsemän kumma veljestä" [Seitse kummalist venda] (Hagman 2016). Raamat tutvustab laiemale lugejaskonnale autori Firenzes kaitstud doktoriväitekirja valitud allikaid. Teoses jutustatakse kohtuasjadele tuginedes seitsme Soomes homoseksuaalsuse eest karistatud mehe elust. Lood on valitud nii, et esindatud on kõik kümnendid 20. sajandi algusest kuni aastani 1971, mil homoseksuaalsus arvati Soome karistusseadustikust välja. Karistatud isikud on provokatiivselt nimetatud Aleksis Kivi "Seitsme venna" peategelaste nimedega. Mõtlesin, et kui Eestis vastav raamat välja anda, kas siis peaks nimed laenama näiteks "Kevade" tegelaskujudelt või võtta hoopis eepose Kalev oma vendadega, et saavutada samalaadne provokatiivne efekt. Sandra Hagmani raamatust tuleb hästi välja selliste kohtuasjade kirjusus kajastatud on nii kahepoolsel nõusolekul toimunud homoseksuaalsed suhted kui ka ühepoolsed ja hierarhilised suhted, aga näiteks ka prostitutsiooni ja ärakasutamisega seotud juhtumid. Esindatud on nii talumehed ja sulased kui suurlinna intellektuaalid, aga ka sõdurid sõjaväljal.

Jaanus Samma ja Sandra Hagmani teosed inspireerisid mind sedavõrd, et otsustasin 2016. aasta varakevadel minna Rahvusarhiivi ja vaadata, kas ma leian homoseksuaalsete inimestega seotud kohtuasju, mis oleksid sama inforikkad ja inspireerivad. Nagu queer või heteroseksuaalsest normist erinevate inimeste lugude kirjutajad on tõdenud, peegeldavad ajalooga tegelevad institutsioonid heteronormatiivseid ühiskondi, mis on normist erineva surunud äärealadele või hoopis maha vaikinud. Arhiivid peegeldavad vaatamata oma nii-öelda objektiivsele jäädvustamiskohustusele ja -lubadusele alati oma aega ja valitsevaid ideoloogiaid. Homoseksuaalsete inimeste ajalukku kirjutamine nõuab sageli uute allikate leidmist või lausa "leiutamist" ning vanade arhiivide uutmoodi kasutamist.

Arhiivitöötajad teavad, et arhiivides võivad ajaloolistel või inimlikel põhjustel tekkinud ebajärjekindlused ja juhuslikkused olla kellegi jaoks suured voorused. Nii tegi ka mind õnnelikuks asjaolu, et mingil põhjusel polnud Eesti Vabariigi aegsetes sõjaväeringkonna kohtu kohtuasjades "sugukõlvatuid tegusid" käsitlevate toimikute pealkirjad varjatud nagu tavaliselt selliste kohtuasjade puhul. Ja nii tootis mugavalt koduarvutist arhiiviinfosüsteemi heas usus sisestatud märksõna "pederastia" kohe kolm prisket tulemust aastatest 1919-1931. ${ }^{3}$

Keerulisemaks läks, kui püüdsin leida selliseid kohtuasju tsiviilelanike kriminaalasjade hulgast. Selgus, et kõik "sugukõlvatute tegude" kohtuasjade pealkirjad on korrektselt varjatud ning ainus võimalus nende uurimiseks oli 
neid lihtsalt massiliselt ja pimesi lugemissaali välja tellida. Korraga sai lugemissaali tellida ainult piiratud hulga toimikuid ning neist igaühe kasutamiseks pidi kirjutama eelnevalt põhjendatud juurdepääsutaotluse ja ootama selle rahuldamist. ${ }^{4}$ Niisiis, kahlasin tunde n-ö pimesi uurimissaali tellitud kohtulugudes, millest enamik käsitlesid vägistamisi ja muid seksuaalkuritegusid, otsides homoseksuaalsuse ajalugu. Olen väga tänulik vastutulelikele Rahvusarhiivi töötajaile, kes püüdsid minu uurimisküsimusi mõista ning mind kõigiti aidata.

Käesolev artikkel on justkui pilootprojekt, minu esimene katse tegeleda nende uutlaadi allikatega. Ma ei oska anda täna ülevaadet, kui palju inimesi Eesti Vabariigi ajal homoseksuaalsete tegude eest kohtulikult süüdistati ja kui paljusid selle paragrahvi alusel karistati ning ma ei tea ka, palju selliseid kohtuasju on tänaseks säilinud. ${ }^{5}$ Vaatlen küllaltki juhuslikku minuni jõudnud tekstikogumit ja püüan uurida, millist infot need minevikulise homoseksuaalse iha väljenduste kohta annavad. Pärast põhjalikku kaalumist käsitlen artiklis just neid esimesena leitud kolme Eesti Vabariigi Sõjaväeringkonna kohtus arutatud juhtumit, kus mehi süüdistati homoseksuaalsuses. Juhtumeid arutati ja uuriti kohtus aastatel 1919, 1929 ja 1931. Vaatamata sellele, et kõiki juhtumeid menetleti sõjaväeringkonna kohtus, on süüdistatavad või kannatanud seotud erinevate institutsioonidega, neil on erinev sõjaväeline staatus ning tegevus toimub eri kohtades. Üks menetletav juhtum toimub Eesti Vabariigi lennuväerügemendi üleajateenija vanemallohvitseri ja reamehe vahel, teine puudutab kahte reameest, kes kannavad arestimajas karistust, ning kolmandas loos uuritakse sõjaväe haigemaja sanitari ja sõjaväega mitteseotud ametniku vahel juhtunut. Niisiis on kõigi lugude kontekst ja tegelased piisavalt erinevad, kuigi kõik on ka mingil formaalsel moel seotud Eesti Vabariigi sõjaväega ning seetõttu menetletakse süüasju just sõjaväeringkonna kohtus. Süüdistatavad on üsna erineva taustaga inimesed, tegelaste galeriid suurendavad veel tunnistajatena ütlusi andnud mehed, kes osaliselt moodustavad süüdistatavate lähiümbruse ning annavad tähtsat teavet lugude konteksti kohta. Erinev on ka see, kuidas n-ö homoseksuaalne iha neis lugudes avaldub: leidub kahepoolsel nõusolekul toimunud seksuaalvahekordi, aga ka hierarhilisi, vägivaldseid või selliseid, mille olemus jääb allikates ambivalentseks. Kohtuasjad tegelevad just seksuaalvahekordadega, mitte näiteks romantilise tunde või armastuse uurimisega - seetõttu on ka toimikutes leiduv info spetsiifiline ning küsimused, mida kohtualustelt või tunnistajatelt küsitakse, peegeldavad just seda poolt. Kuna süüasjadega seotud isikud end homoseksuaalsena vähemalt kohtukulli ees ei identifitseeri ning tolleaegne käsitlus homo- ja heteroseksuaalsusest erineb ilmselt tänastest arusaamadest, siis ongi mingis mõttes selliste mõistetega opereerimine anakronistlik. ${ }^{6}$ Usun, et pederastias süüdistatud meeste kohtuasjad heidavad siiski valgust meie lähiajaloo heteroseksuaalsest normist 
erinevate inimeste maailmale ning annavad võimaluse pilguheiduks sellele osale ühiskonnast, kelle seksuaalsed ihad ei sobitunud tol ajal kehtivate normidega. Kohtuasjad allikatena on teadagi spetsiifilised ja muudavad kahtlemata nii süüdistatavate kui ka tunnistajate hääli, kuid vaatamata filtritele ja moonutustele on sellised allikad siiski täis rikkaid ja tihedaid (kultuuri)kirjeldusi ning võimaldavad teostada mikroajaloolisi uuringuid. ${ }^{7}$ Olen püüdnud kohtuasju vastukarva lugeda ning leida karistamise ja perverssuse diskursusest teavet nende inimeste elude, ihade ja seksuaalsete praktikate kohta. Püüan leida kohtuasjadest, mis uurivad 20. sajandi alguse Eestis kehtivate seksuaalsete normide rikkumist, juhtlõngu, mis annaksid vihjeid tolleaegsete homoseksuaalsete meeste elude ja igapäevase käitumise kohta.

Lisaks kohtuasjadele on minu käsitluse tähtsateks allikateks ka tollases ajakirjanduses ilmunud homoseksuaalsust käsitlevad tekstid, mis lisavad konteksti ning aitavad diskursiivselt raamistada vaadeldavaid toimikuid. Siiski on ka need leitud allikad pigem juhuslikku laadi ega pretendeeri täielikule ülevaatele tol ajal ilmunud homoseksuaalsuse käsitluste kaardistamisele. Eelkõige olen keskendunud tekstidele, mis heidavad valgust tolleaegsetele diskussioonidele homoseksuaalsuse üle ning eriti dekriminaliseerimisele eelnenud aruteludele. Samuti vaatlen põgusalt kriminaalkroonikaid ja kõmurubriike, et näha, kuidas "kollasem" osa ajakirjandusest on homoseksuaalsusega seotud teemasid peegeldanud ning milliseid eelarvamusi taastootnud ja missugust retoorikat kasutanud.

\section{"Pederastia" karistusseadustikes ja diskussioonid selle üle}

Oleme kõik ilmselt kuulnud, et esimeses Eesti Vabariigis kehtiv karistusseadustik oli progressiivne ega kriminaliseerinud täiskasvanute vahel mõlema poole nõusolekul toimunud homoseksuaalseid akte (vt nt Mets 2010: 82). Samas, see kiidetud Eesti Vabariigi kriminaalseadustik võeti vastu alles 26. märtsil 1929. aastal ning hakkas reaalselt kehtima 1 . veebruaril 1935. aastal pärast distsiplinaarseadustiku ja vangistusseadustiku vastuvõtmist ning muudatuste tegemist tollases kriminaalprotsessi korralduses (vt Veiser 2006; Jõeäär 1929). Enne seda kehtisid Eesti Vabariigi territooriumil Ajutise Valitsuse otsusega kõik varasemad seadused, mis olid jõus endise ühendatud Eestimaa ja PõhjaLiivimaa kubermangu piirides enne bolševike võimule pääsemist oktoobris 1917. Niisiis, muuhulgas jäi kehtima ka tsaariaegne nuhtlusseadustik, milles paragrahv 995 käsitles "pederastiat" kui kuritegu. ${ }^{8}$ 
1920. aastate lõpus ja 1930. aastate alguses oli periood, mil eesti ajakirjanduses ilmus mitmeid kirjutisi, mis käsitlesid homoseksuaalsust või muid heteroseksuaalsest normist erinevaid seksuaalsuse väljendusi. Kuigi enamik kirjutisi, kus mainitakse homoseksuaalsust või homoseksuaalseid inimesi, on selgelt kõmulised ning kirjutatud ilmselt lugejate meelelahutuseks ja intrigeerimiseks, viitab selliste kirjutiste olemasolu faktile, et neil teemadel oli võimalik sel perioodil ka avalikus meedias arutleda.

Juba 1924. aastal ilmus Päevalehes teade, et Akadeemiline arstiteaduste selts oli arutanud oma koosolekul homoseksuaalsuse küsimusi. Meditsiinitudeng A. Ibruse ettekanne kandis pealkirja "Homoseksualiteedist naise ja mehe juures" ning referaadi järgi arutati ettekandes muuhulgas ka kaasaegses arstiteaduses aktuaalset küsimust, kas sünnipäraste homoseksuaalsete inimeste karistamine on kohane (Kaks arstiteaduslist 1924). 1. ja 2. mail 1929. aastal esines Tallinnas Estonia kontserdisaalis kahe loenguga kuulus homoseksuaalsete inimeste õiguste eest võitleja ja seksuoloog Magnus Hirschfeld (Prof. dr. med. 1929). Hirschfeldi väidetavalt üsna paljude külastajatega loengud kandsid pealkirju "Õigus armastuse peale" ja "Armastuse eksiteed. Seksualiteet ja kriminaliteet" ning nende sisu refereeriti ka ajakirjanduses (Suguelu päevaküsimusi 1929; Armastuse eksiteed 1929). Loengud olid osa kuulsa Seksuaalteaduste instituudi rajaja ja mitmete mõjukate seksuaalsuse käsitluste autori pikemast ringreisist, Tallinnas toimunud loengutele olid eelnenud loengud Riias. ${ }^{9}$ Esimeses loengus rõhutati liberaalselt, et "suguline rahuldumine on loomulik tarve, mehel ja naisel on ühevääriline õigus armastuse peale, abielu ainus ülesanne ei ole igal juhul lapsi soetada, seega [on] suguviljast kõrvalehoidmine lubatav" (Suguelu päevaküsimusi 1929). Selles loengus puudutati Eestiski tol ajal aktuaalset abordi dekriminaliseerimise küsimust ning kritiseeriti tol ajal mitmel pool maailmas arutatavat "kurikalduvuslike" ja puuetega inimeste steriliseerimise poliitikat. Teises loengus käsitleti homoseksuaalsust ning rõhutati, et kuna tegemist on kaasasündinud eelistusega, siis kohtumõistmisel tuleks käsitleda selliseid inimesi kui haigeid (Armastuse eksiteed 1929).

Magnus Hirschfeldi ideede kajastusi leidus veel paaris Eesti ajakirjanduses avaldatud populaarses artiklis, mis liberaalsemalt või misantroopsemalt käsitlesid homoseksuaalsust ja muid seksuaalseid variatsioone (vt Protens 1928; Inimesed 1928). ${ }^{10}$ 1928. aastal tutvustas Uudislehes Protensi nime taha peituv autor, kes oli 1921. aastal Berliinis Hirschfeldi avalikus loengus osalenud, Saksamaal toimuvat võitlust homoseksuaalsuse dekriminaliseerimise eest. Samas artiklis kirjeldas autor ka oma ebameeldivaid kokkupuuteid homoseksuaalsete meestega Peterburis ja Moskvas. Väga väärtusliku lisana annab autor ülevaate temale teadaolevatest homoseksuaalsete meeste kohtumispaikadest Tallinnas. Autori väite kohaselt otsivad homoseksualistid "ohvreid oma ebaloomulike kirgede rahuldamiseks" Rannavärava mäelt ja Viruvärava Musu- 
mäelt ${ }^{11}$, talviti tänavatel ja kohvikutes, eriti ühes Harju tänava kohvikus ja Viru tänaval asuvas restoranis (Protens 1928). ${ }^{12}$ Ilmselgelt leidub Hirschfeldi ideede kajastusi samal aastal Rahvalehes ilmunud anonüümse autori kirjutatud ülevaates "Inimesed "kolmandamast soost"”, kus rõhutatakse homoseksuaalsuse sünnipärasust ning vajadust moodsa seadusandluse järele, kus selliseid kaasasündinud omadusi ei kriminaliseeritaks. Tähelepanuväärselt analüüsib autor homoseksuaalsust käsitlevat seadusandlust Eestis ning olukorda, kus tsaariaegne nuhtlusseadustik on üle võetud koos selles sisalduva religioosse ideoloogiaga, mille kohaselt oleks tegemist kuriteoga, mis on ka "loomuvastane patt". Tõepoolest, tsaariaegse homoseksuaalsuse paragrahvi kohaselt lisandus homoseksuaalsuse eest süüdi mõistetud isiku karistusele sunnitöö ning kõigi õiguste äravõtmise kõrval veel kiriklik karistus (vt ka Healey 2018: xii-xiii), mis modernses ja pigem ilmalikustunud Eesti Vabariigis polnud ilmselgelt relevantne (Inimesed 1928).

Kui Eestis võeti 1929. aastal vastu uus karistusseadustik, siis vähemalt ajakirjanduses pole jälgi, et avalikult oleks kuigi tuliselt diskuteeritud selle üle, et "pederastia" polnud ühtäkki enam karistatav. Siiski vilksatas avalikus debatis ka homoseksuaalsuse küsimus, kui konservatiivne rahvuslane Helmi Mäelo pahandas avalikus kirjas, et uues karistusseadustikus kavatsetakse abort dekriminaliseerida nagu sotsialistlikul Venemaal (Mäelo 1926: 2). Riigikogu liige ja Eesti Sotsiaaldemokraatlikku Tööliste Parteisse kuuluv Aleksander Jõeäär tõi oma vastukirjutises välja, et ta ei usu, et uues karistusseadustikus plaanitav abordi dekriminaliseerimine, nagu ka pederastia dekriminaliseerimine oleks seotud kuidagi iibeküsimusega.

Kuid kõigi populatsionistlikkude vaadete poolehoidjate kurvastuseks pean tähelepanu juhtima sellele, et kriminaalseadustikust välja on jäetud (ja seda mitte sotsialistide, vaid eelnõu kokkuseadjate ja esitajate poolt) karm paragrahv, mis karistaks pederastia eest. Mina ei julgeks sellest siiski järeldust teha, et lugupeetud õigusteadlased ja riigimehed, kes kriminaalseadustiku eelnõu igakülgselt kaalusid, ja vabariigi valitsus, kes selle esitas, rahva ja riigi seisukohaga ei arvestanud ja et neile meie riigi ja rahva tulevik kallis ei olnud. (Jõeäär 1926: 4)

Aleksander Jõeäär kasutas ilmselt sellist provokatiivset võrdlust retoorilise võttena, mis pidi näitama Helmi Mäelo populistliku loogika ekslikkust. 1920.1930. aastail kuuluski Eestis vasakpoolsete liikumiste kriitikute retoorikasse hirmutamine sotsialistlikul Venemaa toimunud reformidega, mis olevat radikaalselt muutnud ka kõike perekonda, moraali ja seksuaalsust puudutavat. ${ }^{13}$

Homoseksuaalsuse ja selle dekriminaliseerimise küsimus tõusiski veel 1920. aastate lõpus ja 1930. aastate alguses Eesti ajakirjanduses põgusalt 
diskussiooniaineks seoses artiklitega, mis kajastasid kriitiliselt või vähemkriitiliselt Nõukogude Venemaal toimunud revolutsioonilisi muudatusi. Näiteks nädalalehes Nool ilmus tõlkeartikkel "Sissejuhatus armastusgeograafiasse. Nõukogude Vene", kus tutvustati lugejaile Nõukogude Venemaad kui esimest riiki, kus on radikaalselt muudetud traditsioonilisi abielu ja suguelu reguleerivaid seadusi ning kus naised ja mehed on "üheõiguslikud". Keskenduti abielurikkumise, seksuaalvägivalla, abordi ja prostitutsiooni teemadele, aga kirjeldati näiteks ka, kuidas intsesti ja sodoomiat käsitletakse Nõukogude Venemaal uudselt psühhiaatrilise probleemina. Muuhulgas mainiti, et kuritegude loendist on kustutatud "pederastia, lesbiline armastus ja kõik muud "loomuvastase" seksualiteedi vormid" (Istrati 1930: 9). Samalaadne ilmselgelt kõmu taotlev ülevaade Nõukogude Liidu seadusandluse seksuaalsust puudutavast osast anti 1929. aastal ka ajalehe Kaja lugejaile artiklis "Maa, kus naised mehi vägistavad". Selleski artiklis mainitakse, et "üksikud sugulised roimad" nagu homoseksualism on uues seaduses täiesti kadunud. Väidetavalt on homoseksuaalsus jäetud siiski kuriteoks vaid Aserbaidžaanis, kuna nähtus olevat seal erakordselt levinud (Maa 1929).

Ka 1935. aastal kirjeldab Päevalehe Moskva kirjasaatja muutusi, mis Nõukogude Venemaal on toimunud ning demonstreerib perekonda ja seksuaalsust käsitlevate radikaalsete ideede ja seaduste konservatiivsemaks muutumist. Korrespondent tuletab meelde, kuidas Nõukogude ajakirjandus olevat Nõukogude võimu algaastatel pahandanud, et seksuaalsed "eksikalduvused, nagu homoseksuaalsus", olid kodanlikes maades karistatavad. "Sest kuidas võidi karistada haiglasi inimesi, kes oma erikalduvusega ei teinud kellelegi kurja?" Kuid Päevalehe kirjasaatja tähelepanekute kohaselt on 1935. aastaks muutunud nii homoseksuaalsete inimeste õigusi käsitlevad seadused kui ka suhtumine sellistesse inimestesse. ${ }^{14}$

Esimestena tabati uute seadustega muidugi ka ebanormaalseid inimesi, kes ennemalt mängisid revolutsionääre ja mässumeelseid homoseksualiste. Mõlemast soost homoseksualistidele on praegu nähtud ette 5-8-aastane vanglakaristus. Ja kuna Nõukogude seadusandluses tarvitatakse alati ainult teravaid vormuleeringuid, võib selle seaduse järele iga homoseksualisti karistada mitte ainult teolt tabatult, vaid palja kalduvusegi eest. Ning kohe kuulutas Maksim Gorki selle uue seaduse suureks "sotsiaalseks saavutuseks" ja seadis vene lugejaile isegi üles väite, et ainult Nõukogud pü̈̈dvat seda ebanormaalsust välja juurida, kodanlise maailma nuhtlusseadus aga "paitavat" homoseksualiste. (Basseches 1935: 2)

Nagu näha, kasutati ajakirjanduses, isegi kui käsitlus polnud homoseksuaalsete inimeste suhtes otseselt vaenulik, heteroseksuaalsest normist erinevate 
seksuaalsuste kirjeldamiseks sõnu, mis viitasid ebaloomulikkusele või haiglasele: loomuvastane, eksikalduvus, erikalduvus, ebanormaalne.

1920.-1930. aastate Eesti ajakirjanduses tuli homoseksuaalsuse üle arutamist ette ka kirjanduskriitikas ning eriti seoses kõmuliste kriminaalasjadega. ${ }^{15}$ Valmar Adamsi luulekogu "Suudlus lumme" (ilmunud 1924) arvustajad diskuteerisid tuliselt, kas teoses manifesteeritud himurust ja perverssust võiks seostada homoseksuaalsusega (vt nt Jürgenstein 1925; Schwalbe 1925; Luuleharrastaja 1933 jt). Friedebert Tuglase "Felix Ormussonis" (ilmunud 1915) kujutatud moodne tundeline mees pani samuti arutlema homoseksuaalsete inimeste psühholoogia üle (Kiršenberg 1935: 2). Tähelepanuväärselt rõhutati mitmetes üldisemalt homoseksuaalsust käsitlevates artiklites, et homoseksuaalsus on levinud eriti sõjaväelaste hulgas ${ }^{16}$ ja vanglates.

Paar päeva tagasi tapeti kahe lennuväe sõduri poolt Tallinna elanik Oskar Pürn. Nagu kindlaks tehti, oli O. Pürn anormaalsete kalduvustega "meestearmastaja", kes sõduritele tegi ettepaneku ebaloomulikku ühendusse astumiseks, millele sõdurid vastasid surmahoobiga kaikaga pähe. ${ }^{17}$

Niisugune juhtumine ei ole esmakordne. Paar aastat tagasi löödi samasugustel asjaoludel Pärnus maha üks kohalik elanik, homoseksuaal. [---]

Homoseksualiste leidub kõigis seltskonnakihtides. Huvitav on aga see, et neid eriti palju on kõigi maade sõjavägedes, nagu näitab sellekohane teaduslik statistika. Nii ei puudu homoseksualiste ka meie kaitseväes. Aastate eest paljastati niisugused kalduvused ühe kaitseministeeriumile lähedal teeniva noorema aukraadis ohvitseri T. L. juures. (Inimesed 1928)

Ohvreid otsitakse lihtsama välimusega noormeeste seast; peetakse jahti kadettide ning sõdurite peale. [---] Eriti levinenud on homoseksualism meie vanglates. Kuid vägivalla ohvriks langenud vangid ei julge kaebada. Harva ulatub mõni sarnane juhtum ametivõimu kõrva. Vangla paksud müürid ei anna välja oma saladusi; selle eest hoolitsevad vangid ise. (Protens 1928)

1928. aastal kirjeldatakse ajakirjanduses ka juhtumit, kus Tartus tulistab vahipostil olev sõdur "ligi tikkunud" joobnut meest. Ohver osutus olevat "pahaloomuliste kalduvustega, meeste ja poiste armastaja (pederast)", keda oli ka varem selliste tegude eest karistatud. Kuna kuul olevat 59aastase mehe suguosadest läbi tunginud, siis lootis kuritööd kajastav ajakirjanik, et "nüüd lõpetas püssikuul need tembud jäädavalt, ka siis kui mees ise ellu jääb”. Artikkel oli ka pealkirjastatud samas vaimus: "Püssikuul kõrvaldas halva asja" (Püssikuul 1928: 6). 
Ajalehtede kriminaalkroonikates vihjati ohvri homoseksuaalsetele kalduvustele näiteks ka ühe Saaremaal toimunud röövmõrva puhul, kus noorem mees koos abilisega tappis oma vanema usuvenna ja leivaisa. Päevaleht kirjutab juhtumist põhjaliku ülevaate, kus muuhulgas mainitakse, et "Inimeste tõenduse järele olla Reile pederast olnud” (e. 1923). Samamoodi vihjatakse kellelegi Balti aadlist pärineva "meestesõbra" von R-i seiklustele Saaremaal, mis olevat saanud kärarikkalt paljastatud (Inimesed 1928). Ootamatult palju pööratakse toonaste ajalehtede kõmurubriikides tähelepanu n-ö hermafrodiitsete inimestega seotud kohtulugudele, nende isikute anatoomilistele iseärasustele või ka soovahetusoperatsioonide võimalikkusele (vt nt Lätis leiti 1931; Kui mees 1933; Kuidas mehest 1931). Muuhulgas väidetakse ühes looduse "kõrvalhüpete" üle arutlevas artiklis, et hermafrodiidid ehk "naissugupoole tunnustega nooredmehed" olevat kõige levinum tujuka looduse kõrvalhüpetest, mis sõjaväekomisjonides paljastatakse (Looduse 1930).

\section{Queer-ajalugu ja kohtuasjad}

Ajalooliselt on heteronormatiivsesse pilti sobimatud või kehvasti mahtuvad inimesed olnud pahatihti kriminaaliseeritud või patologiseeritud ning ühiskonna äärealadele surutud. Nii on jäänud nende jäljedki nähtamatutele äärealadele ning näiteks karistamise, kontrolli või raviga seotud institutsioonide arhiividesse. Imaginaarsed queer-arhiivid on hõredad ja koosnevad marginaalsetest kildudest. Ühelt poolt pole arhiveerimise ja ajalookirjutusega tegelevad institutsioonid normist erinevate inimeste lugusid ja hääli pigem talletanud (v.a kriminalistika ja meditsiin), teisalt ongi normist erinevatel inimestel olnud repressiivsetes heteronormatiivsetes ühiskondades strateegiliselt ja eluliselt oluline nähtamatuks jäämine. ${ }^{18}$ Nii ongi queer-ajaloo allikateks sageli tekstid, mille eesmärk on ellujäämise pärast varjata ja valetada ning salalikkus on üks queeri allikaid iseloomustav omadusi (vt Muñoz 1996: 6).

Queer-ajaloo teoreetikud on rõhutanud selliste lugude efemeersust ja fragmentaarsust (Muñoz 1996; Cvetkovich 2002: 111), mis peegeldab ka nende lugude allikaid, mis võivad olla radikaalselt teistsugused kui normatiivse ajaloo omad. Allikate loomusest tulenevalt ongi kirjeldatud queer-ajaloo projekti kui traditsioonilisest ajalookirjutusest olemuslikult erinevat. Queer-lood pole tingimata narratiivsed, ei põhine kausaalsetel järgnevustel ega oma koherentset vormi. Sellised lood manifesteerivad püüet tõrjuda teleoloogiat, lineaarsust, põhjuslikkust ja epistemoloogilist meisterlikkust (vt Rohy 2010: 343).

Ann Cvetkovichi järgi peaksid queer-arhiivid säilitama ja tootma mitte ainult teadmisi, vaid ka tundeid. Tema meelest nõuavad gay-ja lesbilood radikaalset 
emotsioonide arhiivi, et dokumenteerida intiimsust, seksuaalsust, armastust ja aktivismi, mida on traditsioonilisse arhiivi kuuluvate dokumentidega raske jäädvustada (Cvetkovich 2002: 110). Queer-arhiivid tegelevad traumaatilise ajaloo puudumisega ja valgete laikudega ajaloos (või ajalookirjutajate pimetähnidega) ning neid on võrreldud teiste traumaarhiividega. Nagu näiteks holokausti, orjuse või sõjamälestuste arhiivid, tegelevad ka queer-arhiivid tõrjutud minevikuga, mida võib olla valus meenutada, kuid mida on võimatu unustada (ibid.). Ann Cvetkovichi järgi järgi meenutab queer-arhivaari tegevus sageli fänni või kollektsionääri suhet oma objektidesse, mis on sageli fetišeeritud, idiosünkreetiline või obsessiivne. Queer-arhivaari ja ajaloolase jaoks on isikliku ja avaliku tegevuse vahe sageli hämardunud (Cvetkovich 2003: 243). Queeri ajalukku lugemine on alati poliitiliselt ja ideoloogiliselt värvunud tegevus. Queeri või homoseksuaalsuse ajalukku sisse lugemine nõuab teatud spetsiifilisi toiminguid. Näiteks on praktiseeritud feministlikus teoorias tuntud vastuseisvaid lugemisviise (resistant reading) ja vastukarva lugemist.

Queer-lugude kirjutajad on rõhutanud vajadust ka tavalisi arhiive queer'ida, st lugeda neid pilguga, mis teeks nähtavaks normist erinevate inimeste jäljed (vt Morris 2006: 147). Üks võimalus uurida normist erinevate inimeste lugusid, ongi pöörduda karistamise ja kontrolliga seotud institutsioonide arhiividesse, ning püüda lugeda end läbi ebanormaalsuse, kriminaalse ja meditsiinilise diskursuse. Kohtutoimikud võivad tunduda väga inforikkad allikad, kuid nendes leiduv teave ja selle esitamise viis on väga spetsiifilised. Need on koostanud institutsioonid, kelle eesmärk on olnud normist erineva kriminaliseeritud ja patologiseeritud käitumise uurimine karistamise ja ühiskonnast eraldamise eesmärgil. Niisiis on selliste dokumentide toon ja ideoloogia ettemääratud ning teavegi selgelt ühekülgne ja "perverssusele" fokusseeritud.

On selge, et näiteks kohtutoimikutes leiduvad puhtsüdamlikuna esitletud ülestunnistused ja kahetsemised pole alati siirad. ${ }^{19}$ Vastukäivad tunnistused ja tunnistuste muutmised ning oma tegude eitamised käivad sageli kohtuasjade juurde. Süüdistatavad varjavad väiksema karistuse nimel oma tegusid ja motiive või annavad neile tõlgenduse, mis aitaks neil päästa oma naha. Toimikuis leiduvaid tunnistusi lugedes saab "lihtsa" tekstianalüüsi abil ka pildi sellest, kes on paremad või kes halvemad valetajad. Samuti on näha, kuidas osa tunnistajaid ja süüdistatavaid on kergemini mõjutatavad kui teised. Lisaks eristuvad naiivsed või naiivsust teesklevad tunnistajad ning külma kõhuga tegelased, kes tunnevad ilmselt paremini seadusi ja oma õigusi, ning tegutsevad julgemalt karistavate institutsioonide seatud piirides.

Kuigi vaadeldavate kohtuasjade süüalused kirjutasid alla dokumendile, kus tunnistasid oma ausust, on selge, et kõigis kohtuasjades tuleb ette varjamist, valetamist ning oma tunnistuste karistuse hirmus korrigeerimist. Trükitud 
"Vande-tõutus", millele vaadeldud kolme kohtuasja tunnistajad alla kirjutavad, sisaldab varjamatut ähvardust võimaliku valetunnistuse eest, see tähendab valetamisel ja varjamisel (nagu ka tõerääkimisel) on väga kõrge hind. Normist erinevad inimesed ongi ilmselt balansseerinud ülekuulamistel õhkõrnal joonel, kus nii tõe rääkimine kui valetamine võivad kaasa tuua karistuse.

Mina tõutan ja vannun, et ma käesolevas asjas oma südametunnistuse järele ainult puhast tõtt tunnistan, suguluse sõpruse, isiklise kasu või vaenu peale vaatamata, ja et ma midagi ei salga, mis ma tean, meeles pidades, et seadus valetunnistust raske karistusega nuhtleb.

Kohtuasjad loovad sageli illusiooni teabeküllusest ning isegi kordustest ja liiasustest. Tunnistuste spetsiifika on see, et erinevad tunnistajad jutustavad sama lugu mitmeid kordi üha uuesti ümber. Mingit laadi spetsiifilise teabe rohkus tuleneb küsitluse läbiviijate huvidest ja küsimustest, mille fookuses on see, mis on juriidiliselt karistatav, kriminaalne või perversseks loetud. Näiteks küsiti Konstantin T. ja Johannes K. kohtuasja puhul nendega samal ajal karistust kandnud või haiglaravil olnud noormeeste käest väga sarnaseid küsimusi, mistõttu saadi suures osas identseid või sarnaseid tunnistusi. Vaadeldavate kohtuasjade puhul on tunnistajate ütlused vormistatud enamasti monoloogina, nii et uurija küsimused jäävad varjatuks. Konstantin T. ja Johannes K. juhtumi puhul on kongikaaslastele esitatud küsimused säilinud siiski ka kirjalikul kujul, kuna üks tunnistaja Voldemar L. oli vahepeal saadetud Tartu vanglasse ning pidi uurija küsimustele vastused andma Tartus. Nagu näha, tulenevad Voldemar L-ile esitatud küsimused suures osas eelnevatest tunnistustest ning annavad vastajale küllaltki palju vihjeid selle kohta, mida teada soovitakse saada (koos magamine, söögijagamine, alasti tantsimine). Samas jäävad küsimata paljud Konstantin T. ja Johannes K. vahekorda puudutavad küsimused, mis homoseksuaalseid suguakte või homoseksuaalset käitumist otseselt ei puuduta.

1) Kas viibis tema 1930 a. ehk 1931 a. Tallinnas garnisoni arestimajas, kui kaua, missuguses kambris (Nr.) ehk mis ajast mis ajani?

2) Kas viibisid temaga ühes kambris v/a.v/a. Konstantin Tja Johannes Kja kas tema neid tunneb ehk mäletab?

3) Kas on tema näinud ehk kuulnud, et Konstantin T ja Johannes Koleks teine teisega suguliselt kokkupuutunud (toimetanud omavahel sugulist akti)? Kui tema seda näinud on siis mida nimelt ehk kuulnud siis mis nimelt ja kelle käest?

4) Kas tema on kuulnud, et Johannes K-d kambris nimetatud Konstantin T "naiseks", kes teda niiviisi nimetasid, ehk et Konstantin Toleks rääkinud, et tema on Johannes K-ga “abielus”? 
5) Kas tema on näinud, et Konstantin T Johannes K-d kostitas suitsudega ja oma arestimaja supiga? Kas juhtus seda ainult Konstantin T ja Johannes Kvahel, või oli see üldiseks pruugiks, et üksteist vangikambris kostitas? Kui sarnane kostitamine üldiseks pruugiks ei olnud, mis põhjustel sündis see just Konstantin T Johannes K vahel?

6) Kas on tema näinud, et Johannes Koleks teiste v/a.v/a. ees kambris ihualasti tantsinud? Mis puhul sündis sarnane tantsimine?

7) Missugune oli Konstantin $T$ ja Johannes $K$ läbisaamine ehk nende läbisaamine teiste vahialustega üldiselt?

8) Kas teaks tema midagi iseäraliku Konstantin T ja Johannes K vahekorra kohta tunnistada ja mis nimelt?

9) Kas oleks temal veel ehk midagi asja kohta tunnistada? (Juhtum arestimajas)

On selge, et ei sellised väga spetsiifilised küsimused, ega ka neutraalsemad stampküsimused ei suuda avada kohtualuste kõiki motiive ja taustu. Kohtuasjad võivad jätta küll mulje infoküllusest, ometi on need täis lakuune ja vastamata küsimusi. Kuna juhtumi uurijaid huvitavad vaid pederastia paragrahvi alla mahtuvad suguaktid, aga ka "pederastiale" viitavad käitumismallid, siis on ka kogutud materjal suures osas ühekülgne ning ainult seda poolt kajastav. Siiski leidub tunnistajate ja süüdistatavate monoloogides juhuslikke infokilde, mis heidavad valgust näiteks ka tunnetele või normist erinevate inimeste igapäevastele praktikatele - kõigele sellele, mis pakub huvi queer-ajaloole.

\section{Tegelaste galerii}

Vaatlen järgnevalt kohtuasju, kus täisealisi mehi süüdistatakse pederastia katses või pederastias, millega peeti tolleaegsete seaduste kohaselt silmas anaalset suguakti kahe mehe vahel. Paragrahvi kohaselt olid karistatavad mõlemad osapooled sõltumata nende rollist. ${ }^{20}$ Kuigi süüdistus ja paragrahv on üks, on tegemist väga erinevate lugudega. Kohtupingis istuvad mehed olid küllaltki erineva taustaga ja nad kõik ei mahu ilmselgelt probleemitult ka tänapäevasesse homoseksuaalsuse kategooriasse. Toimikud demonstreerivadki muuhulgas ilmekalt, et minevikus eksisteerinud normist erinevaid seksuaalsuse ja iha väljendusi ei saa üksüheselt taandada mingiteks tänapäeval tuntud seksuaalseteks identiteetideks. Homoseksuaalsuse mõiste, nii nagu me seda täna defineerime, ongi väga uus, ja oleks anakronistlik püüda seda kleepida külge minevikus elanud inimestele. Modernne läänelik homoseksuaalsuse mõiste katab igasugust oma sugupoolele suunatud seksuaalset iha ja käitumist, sõltumata sellest, kas 
see on ühepoolne ja hierarhiline või kahepoolne ja vastastikune, kas see on sooliselt polariseeritud või polariseerimata, kas see on latentne või aktuaalne, mentaalne või füüsiline. (Halperin 2000: 110.) ${ }^{21}$ Meeste homoseksuaalsuse ajalugu uurinud David M. Halperin on jaganud eelmodernseid homoseksuaalse iha ilminguid neljaks prehomoseksuaalseks kategooriaks (naiselikkus; pederastia või aktiivne sodoomia; sõprus või meestevaheline armastus; passiivsus või sooline inversioon), mis pole modernsed orientatsioonid või seksuaalsed eelistused, vaid lähtuvad mingitest muudest aspektidest (Halperin 2004).

Kohtutoimikud on dokumendid, kus inimestel oli kasulik oma n-ö normist erinevaid kalduvusi varjata. Seetõttu räägin nende kohtuasjade puhul üldistavalt homoseksuaalsest ihast ega püüa eristada tänapäevase homoseksuaalsuse mõiste sisse paremini mahtuvaid isikuid teistest, kes sinna ei mahu.

Kolmes vaadeldavas kohtuasjas süüdistati viit meest pederastias. Lisaks viiele süüdistatavale leidus kohtuasjades ülekuulatud tunnistajate või kannatanute hulgas ka muid isikuid, kelle elus näib olevat olnud homoseksuaalsena tõlgendatavaid episoode või käitumismustreid, nii et vaatamata valimi väiksusele on tegemist natuke suurema portreegaleriiga ning väga inforikka materjaliga. Tähelepanuväärselt ja natuke salapärasel moel jäid vaadeldud kolme kohtuasja puhul kõik süüdistatavad "tõendite puudusel” karistamata.

Tutvustan järgnevalt kokkuvõtlikult juhtumite sisu ning annan tegelaste lühiiseloomustused. Nimetan kohtuasju tinglikult toimumiskoha järgi juhtumiteks haigemajas, kasarmus ja arestimajas. Kõik isikud on esitatud vaid eesnimedega ning kohtuasjade täpseid viiteid pole antud, neile on viidatud vaid tinglike pealkirjadega.

\section{Juhtum haigemajas}

Johannes A., 30 a, Sõjaväe Varustus Valitsuse Ehitus- ja Korteri osakonna asjaajaja k.t. Perekonnaseis: abielus, 1919. aastal sündis tütar. Haridus: 3 klassi linnakooli. Elukoht: Tallinn, Müürivahe tn.

Voldemar R., 24 a, sõjaväe haigemaja sanitar. Perekonnaseis: vallaline. Elukoht: Harjumaa, Kohila vald, elab Tallinnas, Hollandi tn.

Johannes R., 45 a, kaupmees. Perekonnaseis: abielus. Haridus: algharidus. Elukoht: Harjumaa, Nehatu vald, elab Tallinnas, Riesenkampfi tn.

Johannes A-d süüdistatakse selles, et "tema 8. septembril 1919. a. Tallinnas Narva maanteel Nr. 46 II sõjaväe haigemaja ruumides sellesama haigemaja sanitariga Voldemar R-ga katset tegi temaga sugulist läbikäimist toimetada, 
ettekavatsetud kuritegu aga toime panna ei jõudnud, temast mitte äraolevatest põhjustest".

Juhtum on huvitav, kuna annab sissevaate sellesse, kuidas 20. sajandi alguses normist erineva seksuaalsusega mehed tutvusid ja käitusid linnaruumis. Kohtuasi ei anna vastust küsimusele, miks varemgi homoseksuaalsete meestega kohtunud Voldemar R. valmistab lõksu Johannes A-le, kes tuleb kokkulepitud kohtumisele haigla territooriumile, kus Voldemar R-i kolleegid nad teolt tabavad. Johannes A. ja Voldemar R. tunnistustest saab teavet ka muude homoseksuaalsete episoodide kohta, mida selles kohtuasjas ei käsitleta. Johannes A. eitab kõike toimunut ning pakub toimunule seadusega kooskõlas olevaid seletusi. Johannes R. on üks mõlema asjaosalisega seotud tunnistajatest, kelle tunnistustest tuleb välja, et ta on praktiseerinud heteroseksuaalsest normist erinevaid seksuaalsuhteid.

\section{Juhtum kasarmus}

Ernst R., 27 a, lennuväe rügemendi lennukooli aviomotoristide klassi õpilane, vanem allohvitser (osalenud Vabadussõjas). Perekonnaseis: abielus, lapsi ei ole. Haridus: 6 klassi algkooli. Elukoht: Harjumaa, Kohila vald, elab Tallinnas, Loo tn.

Harald L., 21 a, lennuväe rügemendi eskadrill N 9 reamees (põllutööline). Perekonnaseis: abielus, lapsi ei ole. Haridus: 2 klassi algkooli. Elukoht: Läänemaa, Paadremaa vald.

Ernst R-i ja Harald L-i süüdistatakse selles, et “ööl vastu 22. novembrit 1929. a. Lennuväe kasarmus, Lennukooli ruumis kokkuleppel toimetasid sugulist läbikäimist üksteisega loomuvastasel teel pärasoole kaudu".

Tunnistustest tuleb välja, et Ernst R-i elus on ka varem ette tulnud homoseksuaalsusele viitavaid episoode ning et mõned tunnistajad on teda varemgi "pederastias" kahtlustanud. Harald L-i ja Ernst R-i juhtum on selgelt hierarhiline, kus vanem, haritum ja auastmelt kõrgem kasutab teist osapoolt ära. Mõlemad asjaosalised eitavad esialgu toimunut. Juhtum saab avalikuks tänu samas ruumis viibinud tunnistajale.

\section{Juhtum arestimajas}

Konstantin T., 25 a, 1. soomusrongi rügemendi reamees (sepp), kandmas kolmeaastast karistust varguste ja teiste süütegude eest. Perekonnaseis: vallaline. Haridus: 3 klassi algkooli. Elukoht: Saaremaa, Laimjala vald. 
Johannes K., 22 a, 1. suurtükiväegrupi reamees (põllutööline), kandmas kaheaastast karistust sõjaväeteenistusest põgenemise eest. Perekonnaseis: vallaline. Haridus: 3 klassi algkooli (teisal "1 tali vallakoolis"). Elukoht: Viljandimaa, Tarvastu vald.

Konstantin T-d ja Johannes K-d süüdistatakse "selles, et nemad viibides vahi all Tallinna Garnisoni arestimajas, aja jooksul oktoobri kuust 1930 a. kuni 1. jaanuarini 1931 a, kokkuleppel süstemaatiliselt toimetasid sugulist läbikäimist üksteisega loomuvastasel teel pärasoole kaudu".

Juhtum on huvipakkuv, kuna tegemist on ilmselt mõlema osapoole vabal tahtel toimunud regulaarse seksuaalsuhtega. Tunnistustest tuleb välja, et kumbki osapool pole oma seksuaalsuhtest saladust teinud, vaid on sellest oma piiratud kogukonnale avalikult rääkinud. Konstantin T. siiski eitab ülekuulamistel millegi ebaseadusliku toimumist, Johannes K. räägib toimunust esimestel ülekuulamistel, kuid muudab hiljem oma ütlusi.

\section{Kohtutoimikute keel ja homoseksuaalsest ihast rääkimise viisid}

Kohtutoimikute keel on rõhutatult ametlik ja isegi tunnistajate kõne on enamasti tõlgitud sellesse kantseliitlikku kontrolli ja karistamise keelde. Kuigi tunnistuste paratekstides kasutatakse vormeleid, mis viitavad sellele, nagu vastaks üleskirjutatu täpselt tunnistaja sõnadele, pole see ilmselt tegelikkuses enamasti nii.

Muud midagi käesolevas asjas seletada ei ole. Etteloetud ja õige. (Juhtum arestimajas)

Muud juurde lisada ei tea. Peale eeluurimise lõppu soovin eeluurimise materjali ettenäitamist. Protokoll on kohtualusele etteloetud. Mahakriipsutatud sõna "pakkus" mitte lugeda. Pealekirjutatud "andis" ja vahele kirjutatud - "suguline”, "mina” ja "kas tema”- õige. (Juhtum kasarmus)

Sellele, kuidas protokollitud tunnistused on ühtlustatud uurimistoiminguid tegevale institutsioonile sobivasse keelde, viitavad tekstides teatud vormelid ja mõisted, mis ilmselgelt ei kuulu ülekuulatud noormeeste leksikasse. Niisiis, nii nagu on kadunud palju detaile sellest ajaloolisest homoseksuaalse iha maailmast, on jäänud ilmselt ametliku kohtukeele varju ka selle marginaalse rühma loomulik keelekasutus. Homoseksuaalsete seksuaalsete praktikate kohta kasutatakse kohtuasjades enamasti ümberütlevat terminit "loomuvastane vahekord" või "loomuvastane suguline läbikäimine". Kuna see termin on ka 
vähese haridusega noorte poiste tunnistustes, siis on ilmne, et nende tunnistused on "tõlgitud" kohtudokumentidele sobivasse keelde.

Aleksander L.: Konstantin T vahest andis Johannes K-le suitsusi, kui temal oli. Mis puutub Konstantin T ja Johannes K loomuvastasse vahekorda, nimelt sugulisse läbikäimisse nende vahel, siis isiklikult mina niisugust asja pealt näinud ei ole, aga mõlemad, nii Konstantin T kui Johannes $K$ rääkisid sellest kambris avalikult. (Juhtum arestimajas)

Distsiplinaar kompanii vahialune rms Johannes $K$ tunnistab puhtsüdamlikult õigeks sarnastest toimingutest Konstantin T-ga osavõtus ja tunnistab end ka sü̈̈li loomuvastastes asjades, kuna vahialune rms Konstantin T oma kordasaadetud tegusid täiesti eitab ja ennast loomuvastastes toimingutes Johannes K juures sü̈̈di ei tunnista. (Juhtum arestimajas)

Samalaadne haritud inimeste ümberütlev väljendus on näiteks Harald L tunnistuses leiduv "iseäralik suguline tung meeste vastu”. Samas tunnistuses on siiski kasutatud ka natuke madalamast registrist verbi "käperdama".

Harald L.: Seda, et Ernst R-l olema mingisugune iseäralik suguline tung meeste vastu, märkasin juhuslikult korra varem, sest on küll juba tükk aega tagasi, ei mäleta millal, olin sauna korrapidajaks Lasnamäel, kus kõik olid saunas ära käinud - saunas oli Ernst R üksinda ja tema kutsus mind oma jalgu masseerima, mida mina ka temale tegema hakkasin. Seal siis hakkas Ernst $R$ mind samuti käperdama nagu viimane kord voodis ja minul ei jäänud muud üle kui saunast lahkuda. (Juhtum kasarmus)

Kuigi Eesti Vabariigis 1929. aastal kehtima hakanud kriminaalseadustikus oli kasutatud juba pederastia mõistet, tuleb umbes samal ajal toimunud kolmes kohtuasjas seda sõna üliharva ette, kuna eelistatakse eespoolnimetatud ümberütlevaid termineid. Sama harva kasutatakse ka terminit homoseksuaalsus.

I jsk sõjaringkonna uurijale: Vastutusele võtmiseks pederastlikus sugukõlvatuses, milline sü̈̈tegu on ettenähtud N.S \$ 995. (Juhtum kasarmus)

Arsti küsimuse peale, kas tema on kunagi varem olnud kellegagi homosexuaalses vahekorras, vastas Johannes $K$ samuti eitavalt, kuid küsimuse peale, kas tema on olnud sarnases vahekorras Konstantin T-ga, seletas et paar korda on olnud, kusjuures pealekäijaks ja mõtete tekitajaks ja niisamuti ka selle vahekorra seletajaks on olnud v/a T, kes õpetanud teda asendi võtmises, et teised seda ei näeks. Vahekorras olnud nemad T-ga ööseti. Peamiselt sündinud temal kokkupuutumine T-ga suitsude saamiseks. (Juhtum arestimajas) 
Lisaks neile ümberütlevatele terminitele või ametlikele võõrsõnalistele nimetustele leidub tunnistajate kõnes ka vähemlevinud mõisteid homoseksuaalse iha tähistamiseks. Tunnistustes esineb korra näiteks sõna onaniseerima homoseksuaalse vahekorra tähenduses. Arhailine, kuid siiski ametlikust diskursusest pärinev mõiste, peegeldab ajaloolisi arusaamu, mille kohaselt onaania-patt seostus ka homoseksuaalsusega.

Martin K.: (sm komandantuuri vahiülema reamees): 6. skp. öösel pidult kodu tulles kõlistas $v$. allohvitser $R$ kaks korda reamees B-le ja käskis oma poole tulla. Reamees $B$ esimene kord vabandas, et ta juba riidest lahti ja tulla ei saa, kuid pärast lubas minna. Kas ta käis, mina ei tea. Kuulsin juttu telefoni kaudu pealt. Endisest koosseisust reamees $S$ rääkis minule, et allohvitser $R$ onaniseerida. Arvan, et rms $S$ minule tõtt rääkis, sest ta usaldas mind. Rms $T$ käis $v$. allohvitser $R$ käsul viimase toas 12 . vastu 13 skp. öösel umbes kella 3 ajal. (Juhtum kasarmus)

Mõnele kohtuasja tunnistajale tundub ilmselt, et nad peavad näitama ennast võimalikult naiivsetena, et mitte saada samasugust "pederastia" süüdistust nagu nende tuttavad. Näiteks tunnistaja Alfred M. tunnistab, et vahialune Johannes K. kutsus teda haiglas enda kõrvale magama, kuid ta ei taibanud esialgu, miks seda tehti. Siis olevat Alfred M-ile tulnud meelde, et ta on ajalehtedest "niisugustest vahekordadest" lugenud.

Alfred M.: Johannes Kja Konstantin T loomuvastasest läbikäimisest sain kuulda nende enda käest nende eneste jutust. Kui olime koos Johannes $K$-ga keskhaigemajas, kutsus v / a Johannes K mind ja v / a P-d oma juure ühte voodi magama seletades, et on niiviisi arestimajas $v /$ a Konstantin $T$-ga koos maganud. Otsekohe Johannes $K$ seda ei nimetanud, mispärast tema meid kutsub enda juure magama, kuid tema seletusest, et Konstantin T-l olevat olnud üks hea suur riist sain aru, milles asi seisab. Muidu mina ehk polekski taipanud, milles asi seisab, kuid olen varemalt ajalehtedes niisugustest vahekordadest lugenud. Ei mina ega P. Johannes K kutse peale Johannes K juure magama ei läinud. (Juhtum arestimajas)

Nii nagu on kadunud palju detaile ajaloolisest homoseksuaalse iha maailmast, ei tunne me ilmselt näiteks ka selle marginaalse rühma "loomulikku" keelekasutust. Siiski on mõningatesse toimikutesse sisse lipsanud ka rahvalikku keelt. Enamasti on see markeeritud otsese kõnega ning obstsöönseid sõnu on häbelikult kolme punktiga markeeritud.

Leonhard M. (nooremarst san lipnik, 28 a): Küsimuse peale, miks ta ennem kutsete peale ei ilmunud vastas reamees Harald L, et "minu peale räägitakse rumalaid jutte, nagu oleks mulle täna öösi p...e taotud, mina 
olen täitsa terve ja minuga ei ole kunagi niisugust asja juhtunud”. (Juhtum kasarmus)

Tunnistajate ja eriti süüdistatavate keel on sageli ümberütlev ja mitmeti tõlgendatav. Seksuaalsete tegevuste kirjeldamiseks kasutatakse laia tähenduste spektriga "andma" või "tegema"-verbe või mõnda muud ebakonkreetset väljendust. Voldemar R-ile saadetud anonüümne tutvumiskiri on täis kahemõttelisi lauseid, mis ilmselgelt vihjavad seksuaalvahekordadele. Kirja saatja Johannes A. tõlgendab hiljem kohtukulli ees neid reetlikke kahemõttelisi kirjakohti osavalt nii nagu tähendaksid salapärased laused vaid seda, et ta soovis haiglas töötavalt Voldemar R-ilt viina osta.

Voldemar R.: Mõni aeg peale selle tuli tema minu juurde ja istusime trepi peale, kus tema minuga katsus mürada ja meelega seejuures minu sugu liiget katsus ja ütles minule "tehke teie minule nü̈d suhu ja siis laske mind omale suhu teha”. (Juhtum haigemajas)

Tutvumiskiri: Võin Teile nii mõndagi teatud asjas pakkuda ja abiks olla kui Teil midagi selle vastu ei ole.

P.S. Teatan Teile, et ka Ed. Leppik, kes teil haige on maja $N 46$ on kaa tubli selle asja tundja mees, kui soovite tehke tutvust, on hea anda laskja. (Juhtum haigemajas)

\section{Lisandused queer-arhiivi: homoseksuaalne iha linnaruumis}

Vaatamata sellele, et vaadeldavate juhtumite süüdistatavad on vanuseliselt ja hariduslikult küllaltki sarnased inimesed, pakuvad kohtuasjad siiski unikaalset infot, mida kuskilt mujalt ei leia. Tegevus, mille eest mehi süüdistatakse, toimub linnas, kuid pooled süüdistatavatest on pärit maalt. ${ }^{22}$ Ilmselt pole siiski nende meeste elus ettetulev heteroseksuaalsest normist erinev seksuaalkäitumine seostatav ainult modernse linnakultuuriga või homosotsiaalsete keskkondadega, kus mehed viibivad. Johannes K. puhul räägivad näiteks tunnistajad, toetudes Johannes K. enda sõnadele, et ta on elanud ebatavalist seksuaalelu juba enne sõjaväge Viljandimaal talukarjusena teenides.

Alfred M.: Veel rääkis Johannes K, et tema juba lapsepõlvest saadik toimetavat niisugust loomuvastast sugulist ühendust, juba karjas käies olevat tema ühe teise karjapoisiga niisugust asja toimetanud. Üldse kiitis tema, et temal pidada niisuguse toimingu juures hea tundmus olema, sest see kutsuvat tema juures esile seemnejooksu. (Juhtum arestimajas) 
Aleksander L.: Johannes K ise, kui temaga vähe tuttavamaks sain, rääkis minule, et tema juba hammu, lapsepõlvest saadik, pidavat niisugust läbikäimist meestega ja et temale see väga meeldivat ning temal olevat hea tundmus. Ka mind kutsus Johannes K korra ööseks oma juure, kuid mina ei läinud. Mis puutub sugulise akti enesesse, siis seda mina küll tõendada ei tea, kas Johannes K ja Konstantin T seda omavahel toimetasid või mitte. Päris kõrvuti nemad magasid küll ja mis nad tegid, kui teised magasid, seda mina ei tea. (Juhtum arestimajas)

Siiski muudel juhtudel kohtuasjad süüaluste minevikus ja väljaspool Tallinna toimunud homoseksuaalse iha väljendusi ei kajasta. Ernst R-i ja Harald L-i ning Konstantin T. ja Johannes K. kohtuasjad paigutuvad spetsiifilisse ja suletud homosotsiaalsesse armee või vangla olustikku. Ernst R-i lugu peegeldab siiski, mismoodi tema sõjaväelises hierarhias kõrgemal positsioonil oleva isikuna saab endale lubada näiteks pidusid alkoholi ning noorte meeste ja neidudega. Samuti on tema liikumisruum laiem reameeste või kinnipeetavate omast, hõlmates ka linna.

Tallinnas tegutsenud haiglasanitari Voldemar R-i ja ametniku Johannes A. kohtuasi on suurepärane allikas, kust saab teada, mismoodi Tallinnas homoseksuaalsete huvidega mehed tutvusid ja kus liikusid. ${ }^{23}$ Toimikule on lisatud Johannes A. poolt valenime all saadetud tutvumiskiri Voldemar R-ile, mis on tõeliselt väärtuslik Eesti queer-ajaloo dokument. Kiri on ühelt poolt asitõend, mis pani Johannes A. ülekuulamisel raskesse olukorda, kuid teisalt see on ka autentne ajalooline dokument, mis annab teavet, mismoodi ja kus homoseksuaalsete huvidega mehed tutvusid, kuidas üksteist pimekohtingutel ära tundsid, kuidas paluti adressaadil vastata, kui see ei peaks soovima kohtuda jne.

Austatud Herra R. 5 /IX 19

Soovin Teiega tutvaks saada, sest H-ra R. on Teist minule nii mõndagi huvitavad rääkinud teatud asjus, oleks väga soovitav kui Teie minu soovile vastu tuleksite ja endal võimalikuks teeksite, kui võimalik on tulla laupäeva õhtul kella 1/2 9-9 Viru uulitsalle Mü̈̈rivahe uul. nurgale, kus on aavatud uus Martenscherski kauplus. Et mina Teid võiksin ära tunda palun märgiks valge nina rätiku nurk frenschi pahema käe ülemise taskust välja panna. Mina saan Teid sell ajal seal ootma.

Võin Teile nii mõndagi teatud asjas pakkuda ja abiks olla kui Teil midagi selle vastu ei ole.

Loodan et Teil midagi selle vasta ei ole et nõnda oma tutvust Teile pakkun, (kirjalikult) kui see ei peaks Teile mitte meele järele olema siis palun Teid minule järgmise adressi all vastata. Müürivahe uul. $35 \underline{\text { k } 5 \mathrm{~J} \text {. Liiver }}$ 
Austades jään lootma, et minule saate vastama ehk ise tulete laupäeva õhtul.

Tervitades J. Liiver

P.S. Teatan Teile, et ka Ed. Leppik, kes teil haige on maja $N 46$ on kaa tubli selle asja tundja mees, kui soovite tehke tutvust, on hea anda laskja. Lootes jään ootama, et tulete kunni nägemiseni

Tervitades Seesama. (Juhtum haigemajas)

Voldemar R lähebki seninägemata härraga kohtuma (võttes julgustuseks kaasa kolleegi) ning seejärel kinno. Pärast filmi saab Voldemar R. Johannes A-lt kutse tulla Lasnamäe paemurdu "sugulisi asju toimetama". Seksuaalset tegevust kirjeldatakse kohtuasjadele iseloomulikus kiretus ja napis stiilis, mis jätab näiteks ambivalentseks, mismoodi Voldemar R. vastas kinos toimunud Johannes A. selgelt seksuaalse iseloomuga lähenemiskatsele.

Voldemar R.: 1919 a. septembri kuu 6 päeval sain mina kellegi tundmata isiku käest kirja J Liiweri allkirjaga, kus mind tutvustamise otstarbeks välja kutsuti. Selles asjas huvitud, läksin mina seda isikut trehvama, kus juures mina sanitar Nikolai M. omaga kaasa kutsusin, et minuga mingid halba ei juhtuks. Minu juuresolevate märkide peale tuli mulle Viru uul. ja Mü̈rivahe uul. nurgal keegi tundmata isik vastu ja küsis, kas mina olen hra. $R$, mis peale mina jaatava vastuse andsin. Selle peale ütles tema, et ta see kirja saatja on ja palus omaga kaasa vähekese aega jalutada. Väikese jalutuse järele läksime temaga Viru uul. pildi näitusesse. Seal hakkas mainitud isik minu sugu liiget katsuma. Pildi näitusest välja tulles tegi kirjasaatja mulle ettepaneku, kas mina ei tahaks mitte "Lasnamäele" paemurru aukudesse temaga kaasa tulla, üteldes, seal on hea meil sugulisi asju toimetada, sest seal ei näe meid keegi. Tema mõttest aru saades palusin mina seda teiseks korraks jätta, vabandades, et mul täna selleks aega ei ole ja määrasime selleks tänase päeva. Sellest asjast teatasin mina oma tuttavatele Richard $R$, Julius $O$ ja Nikolai M’ile ja palusin neid endi trehvamist pealt vaatama tulla. (Juhtum haigemajas)

Järgneva uurimise käigus selgub, et Voldemar R-i elus on olnud siiski ka enne Johannes A-ga kohtumist homoseksuaalsusele viitavaid episoode. Nimelt kutsutakse tunnistama tutvumiskirjas nimetatud abielumehest kaupmees Johannes R., kes tunnistab puhtsüdamlikult, et tal on olnud seksuaalseid kokkupuuteid nii Johannes A. kui Voldemar R-iga. "Johannes A-ga olen mina teineteise suguliiget katsunud," väidab ta, kuigi kinnitab samas, et "temaga sugulisi asju toimetanud ei ole". Samasugune seksuaalne tegevuse olevat toimud ka tema Voldemar R-i vahel: "istusime treppi peale, kus üheteisele sugu liiget katsusi- 
me, kuid temale mina ei ütelnud, et "tehke teie ennem minule suhu, siis mina teen teile," mis mina seal rääkisin, seda mina ei mäleta."

Mis põhjusel Voldemar R., kellel oli olnud ka varasemalt kokkupuuteid meestevahelise keelatud seksuaalse tegevusega, otsustas Johannes A. peale kaevata, toimikust ei selgu. Igal juhul tunnistab Voldemar R. peagi üles ka tema ja Johannes R-i suhte seksuaalsed detailid.

Voldemar R.: Umbes veebruari kuul k.a. käisin mina minule saadetud kirjas ära tähendud H-rra $R$ kaupluses, mis asub Riesenkampfi tänaval $N 13$ ning sain temaga sel teel tutvaks. Sellsamal päeva ôhtul kui mina tema kaupluses käisin ja seal temaga tutvaks sain, tuli tema minule Narvamaanteel maja $N 52 b$ ees vastu; võttis minu käe alt kinni ja hakkas igasuguseid kahtlasi jutusi rääkima kus juures minu sugu liiget katsus, üteldes "küll sul on suur" ja muud teist ja meie läksime varsti lahku. Mõni aeg peale selle tuli tema minu juurde ja istusime trepi peale, kus tema minuga katsus mürada ja meelega seejuures minu sugu liiget katsus ja ütles minule "tehke teie minule nü̈d suhu ja siis laske mind omale suhu teha”. Seda kuuldes lõin mina temale vastu kõrvu ja ajasin teda oma juurest minema. Pärast seda läks juba tükk aega mööda ja tema hakkas minuga jälle tutavaks tegema kutsus mind oma juurde ja rääkis, et temal olla üks tuttav poiss Raua tänaval, kuid nimest tema ei ütelnud, kelle juures tema olla maganud. Muud minul selles asjas enam juurde lisada ei ole. (Juhtum haigemajas)

Voldemar R-i ja Johannes A. kohtuloo abil on jäädvustatud selle homoseksuaalse afääri geograafia ja marsruudid Tallinna linnaruumis. Vanalinna kinod ja kauplused, Narva maantee hoovid ning Lasnamäe looduslikud ja inimtekkelised maastikud on omanud vähemalt selle loo peategelaste jaoks salajasi seksuaalselt laetud tähendusi. Johannes A. lisab sellele kaardile veel Kadrioru pargi ning ilmselt ühe tüüpilise tutvumisloo (kohtule esitatud alternatiivne versioon esmakohtumisest).

Johannes A.: 1919 a. juuni kuus, kuupäeva ei mäleta, sain mina Voldemar R-iga õhtu hilja Kadriorus tuttavaks ja nimelt selle läbi, et mina temalt suitsu peale tuld palusin, mis tema ka mulle kohe lahkeste andis, kus juures meie pikemasse jutuajamisesse saime. Peale selle oleme vahel kui kuskil trehvame, mõne sõna juttu ajanud. Täna mõtlesin mina temaga jälle kokku saada, et temalt küsida, kuidas tema elab ja mis teeb. (Juhtum haigemajas) 


\section{Patologiseeriv vaade: homoseksuaalne loomus ja keha}

Pederastias süüdistatud meeste kohtu-uurimise praktikas olid tavalised meditsiinilised läbivaatused. Samas 1920.-1930. aastateks oli meditsiin siiski arenenud nii kaugele, et vähemalt neis kolmes kohtuasjas ei suutnud arstid tuvastada mingeid "objektiivseid" viiteid homoseksuaalsusele või homoseksuaalsetest praktikatest tingitud füüsilisi muutusi kohtualuste kehadel. Süüalused vaatas läbi arstlik komisjon, kes hindas peale uuritavate füüsilise seisundi ka vaimset seisundit ning püüdis tähelepaneliku suguelundite vaatluse kaudu leida jälgi, mis viitaks homoseksuaalsusele.

Sü̈̈distusaluse Konstantin T ülevaatusel selgus: Väliselt kehaliselt normaal, väljaarvatud kõrge kurgulagi. Mõlemite reite peal tetoveeritud joonistused kuni põlvedeni. Arsti küsimuse peale, kas tema homosexuaalses vahekorras on olnud kunagi, vastas Konstantin T eitavalt. Suguosad normaalselt kujunenud ja arenenud. Ka nende juures tundemärke, mis võiks oletada lubada homosexuaalset vahekorda, leida ei olnud. Vaimliselt osutus normaalseks.

Sü̈̈distusaluse Johannes K ülevaatusel selgus: Kehaliselt normaalselt arenenud. Passiivse poolse homosexuaalse vahekorra tundemärke ei leidu. Vaimliselt normaal. (Juhtum arestimajas)

Kuigi nendes kolmes kohtuasjas arstid süüdistatavatel mingeid füüsilisi homoseksuaalsusele viitavaid tunnuseid ei leidnud, rõhutatakse kahel juhul n-ö passiivse osapoole vaimset mahajäämust või ebanormaalsust. Johannes K. puhul märgivad seda tema kongikaaslased (kuid mitte arstlik komisjon), kes rõhutavad, et Johannes K. ei oska lugeda ja kirjutada ning on "arenemata". Samuti rõhutavad Johannes K. palati- ja kongikaaslased tema ekstravagantset käitumist: ta on pehme ja naiselik, käib käpuli nagu loom, tantsib häbi tundmata ja alasti.

Aleksander L. (21 a): Johannes $K$ paistis olevat arenemata, ei osanud lugeda ega kirjutada, käis vahest kambris käpuli nagu loom jne, mis näitas, et tema kui mitte just nõrga mõistuse juures polnud, siis vähemalt küll õige arenemata oli. Konstantin T oli väga viisakas ja sõbralik poiss. (Juhtum arestimajas)

Dimitri P. (24 a): Üldiselt niipalju, kui mina Johannes K-d tunnen, on tema küll väga naiselik ja pehme nii omas olemises kui ka iseloomu poolest. Keskhaigemajas mäletan tantsis tema teiste haigete ees ihualasti tantsusi, mida teised vahialused teda tantsima olid õpetanud. Ühtedele see ei meeldinud ja nemad keelsid teda niisugust asja tegemast, teised lihtsalt naersid Johannes K üle. (Juhtum arestimajas) 
Voldemar V. (22 a): Mina isiklikult küll näinud ei ole, et Johannes Kja Konstantin Toleks omavahel loomuvastaselt suguliselt kokku puutunud, muidu aga oli v/a Johannes K küll niisugune mees, et temast seda ehk arvata võiks, sest iseloomu poolest ja olemise poolest oli tema õige naiselik. Olen ise näinud, kui tema vahest särgiväel ilma püksata kambris teiste ees tantsis. (Juhtum arestimajas)

Verner S. $(23$ a): Ihualasti pole mina näinud Johannes $K$-d kambris tantsivat, tema tantsis küll, kuid oli riides. Mispuhul Johannes K tantsis, seda mina ei tea. (Juhtum arestimajas)

Harald L-i ja Ernst R-i juhtumi puhul läbis arstliku kontrolli vaid passiivne osapool, kes viidi paar päeva pärast väidetavat suguühet arsti juurde läbivaatusele. Kuigi arst tunnistas, et ta ei näe Harald L-i kehas midagi iseäralikku, mis viitaks homoseksuaalsele vahekorrale, siis näeb ta siiski tema füüsises väidetavalt "psühhopaatilisele konstitutsioonile" viitavaid jooni.

Välisel ülevaatusel, mis leidis aset, kui ei eksi, kolmandamal päeval, mina mingisuguseid andmeid selle fakti kohta ei leidnud. Harald L-i kohta pean küll tunnistama, et see paistab minule küll olevat täiesti psühhopaatilise konstitutsiooniga isik. Ernst $R$ on täiesti normaalne inimene. Muud juure lisada ei tea. (Juhtum kasarmus)

Kõik kolm kohtuprotokolli püüavad objektiivsuse ja teadusliku täpsuse poole ning seetõttu kopeerivad meditsiinilist sõnavara. Konstantin T. ja Johannes K. enam kui paar kuud kestnud vastastikulisel nõusolekul toimunud seksuaalne läbikäimine taandatakse kohtu ees anatoomiliselt naturalistlikuks küsimuseks, mis ei räägi millestki muust kui ainult suguliikmest, pärasoolest ja seemnest.

Kas kohtualune Johannes $K$ [---] on sü̈̈di selles, et viibides Tallinna garnisoni arestimajas vahi alla, tema ajajooksul 16-st oktoobrist 1930 a kuni 1-se jaanuarini 1931 a kokkuleppel teise isikuga teadvalt ja tahtvalt toimetas sama teise isikuga sugulist läbikäimist sel teel, et laskis sel isikul pista suguliikme tema Johannes $K$ pärasoolde sugulise akti sooritamise otstarbel, kusjuures see teine isik oma seemne laskis voolata tema pärasoolde? (Juhtum arestimajas)

Mis tegelikult nendes sõjaväe ringkonnakohtu poolt süüdistatavate meeste vahel juhtus, jääb suures osas saladustelooriga kaetuks. Protokollid on täis vastukäivaid ütlusi ja räägivad üldjuhul ainult kehadest ning annavad edasi kõrvalseisjate muljeid. Tundeid, mida queer-ajalood otsivad, on neis eksplitsiitselt väga napilt. Süüalused muudavad oma ütlusi ja räägivad ennast sisse, kuid jäävad imelikul kombel sellel liminaalsel ajal, kus homoseksuaalsus oli veel karistatav, siiski karistamata. 


\section{Ajalugu, mis oli}

Nii nagu mulle tuli üllatusena, et Eesti Vabariigis üldse toimus protsesse "pederastias" süüdistatavate üle, tuleb paljudele ilmselt üllatusena, et sellised lood ja inimesed on 20. sajandi alguse Eestis olemas olnud. Ajaloolised heteroseksuaalsest normist erineva iha väljendused on üks marginaalne ja mahasalatud osa meie lähiajaloost ning kohtuasjad on käegakatsutavad tõendid, et need normist erineva seksuaalse identiteedi või seksuaalsete eelistustega inimesed olid olemas. Kuigi see varjatud ja paralleelne maailm pole jätnud endast palju jälgi, võiksid nende meeste kohtuasjadest välja kooruvad lood olla alternatiivid ja täiendused tuntud ajaloonarratiivide ja armastuslugude kõrvale.

Suurem osa 1920. ja 1930. aastatel ajakirjanduses ilmunud homoseksuaalsuse käsitlustest on misantroopsed ja teatud eelarvamusi taastootvad, muuhulgas rõhutatakse tähelepanuväärsel moel näiteks homoseksuaalsuse levinemust militaarsetes institutsioonides. Siiski leidub ajakirjanduses ka tekste, kus vahendatakse tol ajal Euroopas aktuaalseid ideid selle kohta, et homoseksuaalsus kaasasündinud omadusena ei tohiks olla kriminaalselt karistatav.

Pederastiat käsitlevad kohtuasjad on oma olemuselt vägivaldsed ning rõhutatult seksile keskenduvad tekstid. Oma perverssusele ja süüdistamisele keskenduva loomuse tõttu on need väga ühekülgsed ja halvad inimeste portreteerijad. Protokollivad instantsid moonutavad tunnistajate ja süüdistatavate keele kummaliseks kohtukeeleks ning ka süüdistatavad ise teevad kõik, et endast vähem teavet jagada. Süüdistatavad valetavad ja varjavad või teevad meeleheitlikke ülestunnistusi, kuid info mis protokollidesse kirjutatakse, on kummaliselt ühekülgne ja pealiskaudne.

Siiski lahvatavad aegajalt mõned infokillud, mis heidavad enam valgust süüdistatavate eludele, igapäevastele toimingutele või nende homoseksuaalse iha loomusele. Kui nappus ja juhuslikkus iseloomustab üldisemaltki queer-ajaloo allikaid, siis kohtutoimikud on spetsiifiliselt napp tekstiliik. Kriminaliseeritud homoseksuaalset iha on olnud mõistlik varjata, liiatigi kohtukulli ees.

Mingit esinduslikku ja katvat tekstikogu või andmepanka homoseksuaalsete inimeste elude kohta 20. sajandi alguse Eestist pole olemas. On vaid vähesed homoseksuaalsete inimeste päevikud või kirjavahetused ning kogu info tuleb koguda tekstidest ja miks mitte ka artefaktidest, mida pole säilitatud eesmärgiga jäädvustada homoseksuaalsete inimeste või queer-ajalugu. Kindlasti on Eestis arhiive ja tekste, mida oleks tulemuslik queer'ida ehk lugeda neid nii, et homoseksuaalsed inimesed ja nende ihad ei jääks pimetähniga kaetuks.

Vaatamata oma spetsiifikale on "pederastia"-kohtuasjad siiski oluline lisandus Eesti queer-ajalukku. Käsitletud kolmele sõjaväeringkonna kohtu kohtuasjale lisaks leidub selliseid kohtuasju ka tsiviilkohtute materjalide hulgas, mille läbitöötamine tulevikus võiks rikastada meie teadmisi kohalikust queer-ajaloost. 


\section{Kommentaarid}

1 Artikli valmimist on toetanud Haridus- ja Teadusministeeriumi uurimisprojekt IUT 22-4 "Folkloor kultuurilise kommunikatsiooni protsessis: ideoloogiad ja kogukonnad", Euroopa Liit Euroopa Regionaalarengu Fondi kaudu (Eesti-uuringute Tippkeskus - CEES) ja KONE fondi ja Helsingi Ülikooli uurimisprojekt "Omistajuus, kieli ja kulttuuriperintö - Kansanrunousideologiat Suomen, Karjalan tasavallan ja Viron alueilla".

${ }^{2}$ Kasutan siin ja edaspidi mõistet queer, millega tähistatakse kõiki seksuaalseid ja soolisi identiteete ja nende ilmnemisviise, mis erinevad heteroseksuaalsest normist või ei allu binaarsele ettekujutusele soolisusest. Eesti keeles pole üheselt aktsepteeritud vastet mõistele leitud, kasutatud on näiteks kväär (vt Feeling 2014), milles sisalduv sõna "väär" vihjab ka ingliskeelses originaalis olevale veidruse assotsiatsioonidele (vrd soomekeelseks vasteks pakutud sõnade pervo ja outo tähendusi). Queer-teooria uurib, kuidas "normaalsust" ja "ebanormaalsust" konstrueeritakse ja ülal peetakse ning käsitleb nii hetero- kui ka homoseksuaalsust ajalooliste ja juhuslike kategooriatena ega püüa selliseid kategooriaid universaalsetena erinevate kultuuride või aegade käsitlemisel aluseks võtta. Eesti kunstnikest on queer ajalooga süvitsi tegelenud veel varalahkunud Anna-Stina Treumund (1982-2017). Tema kunstiprojekt "Lilli, Reed, Frieda, Sabine, Eha, Malle; Rein ja Mari" (2001) visualiseeris fragmente 16.-20. sajandi Eesti-ja Liivimaa queer-inimeste eludest, toetudes näiliselt juhuslikele leidudele arhiividest ja ajakirjandusest ning suulisele pärimusele (vt ka Triisberg 2017).

${ }^{3}$ Hiljem leidsin, et üht neist kohtuasjadest on lugenud ka ajakirjanik Pekka Erelt, kes jõudis selleni ehk samuti samasuguse "lihtsa" otsingu tulemusel (Erelt 2014).

${ }^{4}$ Queer-ajaloo uurijad on oma uurimuste refleksiivsetes osades sageli kirjutanud raskustest, mis on ette tulnud, kui on tulnud vastata "lihtsale" küsimusele oma uurimisteema kohta või kui nad on pidanud arhiivides või muudes institutsioonides seletama oma huvi põhjust mingite spetsiifiliste arhivaalide või teemade vastu (vt nt Morris 2006; Freedman 2001: 52, 53; Newton 2000: 221).

5 Hiljuti ilmunud käsitlus Lätis samal perioodil toimunu kohta väidab, et 1920. ja 1930. aastail algatati Riia Ringkonnakohtu (kolme ülejäänud ringkonnakohtu: Liepāja, Daugavpilsi ja Jelgava materjale pole seni uuritud) prokuröri käsul 21 homoseksuaalsust puudutava juhtumi uurimist, millest kuus jõudsid ka kohtu ette (Lipša 2016: 151). Soomes oli meestevahelised "sugukõlvatud teod" karistatavad aastatel 1894-1971, ning sel perioodil karistati selle paragrahvi alusel üle tuhande mehe (Sorainen 1996; vt ka Hagman 2016: 295).

6 Queer-ajaloo uurijad on arutanud, kas peaks kaitsma ajaloolisi isikuid selle eest, et neid seostatakse tänapäevaste läänelike identiteedikategooriatega, mis polnud tol ajal tuttavad või oleksid neid isikuid solvanud (vt nt Freedman 2001: 53).

7 Mikroajalooks nimetatud uurimismeetodi klassikalised esindajad tegelesid samuti just kohtuprotokollide uurimisega. 1975. aastal ilmunud Emmanuel Le Roy Ladurie teedrajav teos "Montaillou" uuris talupoegade elu, toetudes inkvisitsiooniprotokollidele, samalaadseid allikaid kasutas ka Carlo Ginzburg oma 1976. aastal ilmunud väga mõjukas uurimuses "Juust ja vaglad".

8 Lätis kehtis enne oma kriminaalseadustiku vastu võtmist samuti tsaariaegne nuhtlusseadustik, kus homoseksuaalsus oli kriminaliseeritud. 1933. aasta Läti kriminaalseadustikus jääb homoseksuaalsus kuritööks, mille karistuseks on seaduses täpsemalt määratlemata ajaga vangistus (vt Lipša 2016: 146). 
9 Magnus Hirschfeld oli Riias loenguid pidanud juba ka 1926. aastal, millele järgnesid tema loengud Nõukogude Liidus (vt Lipša 2016: 149). Mõjukas teoses "Die Homosexualität des Mannes und des Weibes” (1914) oli Hirschfeld maininud, et Liivi- ja Kuramaa aadliperedes on väga palju ehtsaid homoseksuaale (sehr viel echte Homosexuelle) ning suuremates linnades nagu Riias, Liepājas, Jelgavas ja Tallinnas olevat homoseksuaalide kohtumispaiku, mis polevat küll väga rahvarohked. Hirschfeldi väitel leiduvat Riias ka homoseksuaalsetele meestele mõeldud prostituute (vt Veispak 1991: 106; Hirschfeld 1920).

10 1937. aastal anti eesti lugejale teada ka sellest, kuidas Hitler keelustas homoseksuaalsuse "propaganda" ning Magnus Hirschfeldi ühing suleti ja tema väärtuslik arhiiv hävitati (Reinberg 1937).

${ }^{11}$ Ajakirjanduses palju kajastust leidnud väidetavalt homoseksuaalse endise sõjaväeametniku Oskar Pürni mõrvalugu saab alguse samuti Viruvärava mäe turupoolse värava juures, kus mees tutvub kahe noore ajateenijaga. Edasi minnakse Nunnavärava mäe juurde ja sealt Kalamaja surnuaia tagusesse lasketiiru (vt Homoseksualisti 1929).

12 Rahvalehes homoseksuaalsusest kirjutav anonüümne autor mainib homoseksuaalsete inimeste kokkusaamiskohtadena ühte avalikult homoseksuaalsele mehele John R-le kuuluvat kino ja üht kellelegi välismaalasest homoseksuaalile kuuluvat suvitusrajoonis asuvat kohvikut. Autor mainib, et tutvusi püütakse sobitada ka tänavatel ja jalutuskohtades, suvistel kontsertidel, Kadriorus ja randades (Inimesed 1928).

${ }^{13}$ Näiteks Jakob Ploompuu pamflett “Millal sotsialism maailmas maksma hakkab" keskendus suures osas just arutelule sellest, milliseks muutuvad "sotsialismis" inimeste vahelised seksuaal- ja peresuhted (vt Ploompuu 1920).

14 1917. aastal võimule tulnud bolševikud dekriminaliseerisid homoseksuaalsuse 1922. aastal. Stalini võimule tulles (1924) kriminaliseeriti homoseksuaalsed suhted taas 1933-1934, karistuseks homoseksuaalsetele inimestele määrati viis aastat kinnipidamisasutuses ja sunnitöö (vt nt Szulc 2017; Healey 2018).

${ }^{15}$ Lätikeelses ajakirjanduses olevat ilmunud esimene põhjalikum homoseksuaalsust kajastav kirjutis alles 1924. aastal (arvesse pole võetud paarilauselisi krimiuudiseid), kus levitatakse kuulujuttu, et Riias on asutatud pederastide klubi nimega "Must nelk" (Lipša 2016: 146). Läti kõmulisemaid uudiseid on mingil määral kajastatud ka Eesti ajakirjanduses, sellesama homoseksualistide klubi kohtuasjast anti teada 1927. aasta Vabas Maas (Homoseksualistide 1927). 1929. aastal kirjutab ajaleht Esmaspäev toetudes oma Riia kirjasaatjale, et Riias olevat kadunud kaheksa poissi, ning kahtlustatakse, et keegi mees varastab lapsi oma homoseksuaalsete ihade rahuldamiseks. (Kirjasaatjalt 1929: 1). Samalaadse kõmulise loomuga on kirjatükid, mis kajastavad Saksamaal toimunud veretööd, kus keegi homoseksuaalne mees oli väidetavalt 20 poissi tapnud (Hannoveri 1924).

${ }^{16}$ Lisaks Eesti sõjaväega seotud vihjetele ja kõmulugudele käsitleti armees teenivate meeste homoseksuaalsete suhete teemat näiteks ka võõrleegionis teeninud eesti sõduri mälestustes, kes väidab, et palgasõdurite hulgas "laialdaselt on maad võtnud homoseksualism ja joomine" ning kirjeldab fantastilistes värvides väejuhtide reameestest koosnevaid "haaremeid" (Võõra 1932).

${ }^{17}$ Oskar Pürni tapmist kajastatakse ajakirjanduses väga detailselt, sümptomaatiliselt tuntakse kaasa mõrva sooritanud noormeestele ning maalitakse pilt Pürnist kui paadunud ja pahelisest isikust, keda "külastasid alatasa sõdurid ja madrused" (Lasketiiru 1928; Surmahoop 1928; Homoseksualisti 1929). 
${ }^{18}$ Kontrollivate või karistavate institutsioonide eest reetlike isiklike "jälgede" hävitamine ja enesetsenseerimine on olnud homoseksuaalsetel inimestel ellujäämiseks oluline toiming. Ajaloolane Estelle B. Freedman kirjutab näiteks kirjade põletamisest kui sümboolsest aktist, millega queer-elulugude uurijad peavad sageli kokku puutuma ning loetleb oma artiklis Ameerika ajaloos tähelepanuväärseid naispaare, kes on oma isiklikud arhiivid hävitanud (Freedman 2001: 52).

${ }^{19}$ Antu Sorainen, kes on uurinud 1950. aastail Soomes "sugukõlvatute" tegude eest karistatud naisi, näitab et politseiametnikel oli esimese küsitlemise ajal strateegia emotsionaalselt mõjutada naisi, nii et nad kahetseksid oma tegusid. Hiljem kohtuprotsessis käsitleti seda juriidiliselt kui kaalukat ülestunnistust, millel oli kohtuotsusele enam mõju kui naiste edaspidistel tunnistustel (Sorainen 1996, 1998).

${ }^{20}$ Jaanus Samma publitseeritud kolhoosiesimehe kohtuasja puhul on intrigeeriv, et kohtuasi saab alguse kaebekirjast miilitsale, kus noormees, kes on olnud esimehega vahekorras, teeb selle avalikuks. Milline oli noormehe motiiv seda ülestunnistust teha (mis paljastas ka tema enda osalemise kriminaalkorras karistatavates suguaktides), sellele toimikutest vastust ei leia. Võimalik, et noormees ei tundud seadusi ja arvas, et tema enda tegevus ei ole karistatav (vt Samma \& Viola 2015: 5).

${ }^{21}$ Siiski võib ka tänapäeval leida erinevatest Lääne kultuuridestki homoseksuaalse iha väljendusi, mis ei mahu modernse homoseksuaalsuse definitsiooni sisse. Näiteks on uuritud urbanistlikest homoseksuaalse iha väljendustest erinevat maal elavate homoseksuaalsete meeste identiteeti ja seksuaalset eneseväljendust (vt Gray jt 2016). Samuti on kultuuriuurijad tähele pannud mitmeid piiripealseid nähtusi, näiteks on Jane Ward uurinud Ameerika heteroseksuaalseid valgeid mehi, kelle elus tuleb ette ritualiseeritud homoseksuaalse iha väljendusi, mis siiski ei lõhu nende meeste heteroseksuaalset enesekuvandit (Ward 2015).

${ }^{22}$ Olen mujal arutanud eesti talupojakultuuris leiduva homoseksuaalsuse uurimise võimalusi (Kalkun 2010a, 2010b, 2016, 2017)

${ }^{23}$ Käsitlustes, mis uurivad 19. sajandi lõpu ja 20. sajandi alguse homoseksuaalsete meeste käitumist linnaruumis, on olulisel kohal nn cruising-paikade kaardistamine. Vt näiteks 1960. aastate Helsingi homoseksuaalset linnaruumi uurinud Voldemar Melanko käsitlust (Melanko 2012; Ida ja Kesk-Eurpoopa kohta vt nt Cook \& Evans 2014). Eestis on vähesel määral kogutud suulist pärimust linnaruumis leiduvate ajalooliste cruising-paikade kohta Jaanus Samma esimehe-projektiga seoses. Ajakirjanduses on ilmunud ka kaasaegsete mälestusi näiteks Saksa okupatsiooni-aegse homoseksuaalse skeene kohta Tallinnas (vt Liivrand 2007).

\section{Arhiiviallikad}

ERA.927.3.3394; ERA.927.3.3376; ERA.927.3.3375 - Rahvusarhiiv, Sõjaväe Kõrgem Kohus (1918-1940). Kohtutoimikud. 


\section{Kirjandus}

Armastuse eksiteed $1929=$ Armastuse eksiteed. Prof. dr. med. Magnus Hirschfeldi teine loeng. Päevaleht 119, 4. mai 1929, lk 4.

Basseches, Nikolaus 1935. Moraalist ja perekonnaelust Venemaal. Päevaleht 180, 2. juuli $1935, \mathrm{kk} 2$.

Cook Matt \& Evans, Jennifer V. (toim) 2014. Queer cities, queer cultures: Europe since 1945. London: Bloomsbury.

Cvetkovich, Ann 2002. In the Archives of Lesbian Feelings: Documentary and Popular Culture. Camera Obscura 17 (1), lk 107-147.

Cvetkovich, Ann 2003. An Archive of Feelings: Trauma, Sexuality, and Lesbian Public Cultures. Duke University Press.

e. 1923. Kohutav mõrtsukatöö Saaremaal. Kurjategijad kahekskümneks aastaks sunnitööle mõistetud. Päevaleht 269, 9 oktoober, lk 6.

Erelt, Pekka 2014. Eesti Wabariigis anti “pederastia” eest sõjakohtu alla. Eesti Ekspress 41, 8. oktoober, lk 24.

Feeling 2014 = Põldsam, Rebeka (kuraator ja koost). Feeling queezy?! Kõhe tunne?! August-september 2014. Tallinn: Kaasaegse Kunsti Eesti Keskus.

Freedman, Estelle B 2001. 'The Burning of Letters Continues': Elusive Identities and the Historical Construction of Sexuality. Black, Allida M. (toim). Modern American Queer history. Philadelphia: Temple University Press, lk 51-68.

Gray, Mary L. \& Gilley, Brian Joseph \& Johnson, Colin R. (toim) 2016. Queering the Countryside: New Frontiers in Rural Queer Studies. New York University Press.

Hagman, Sandra 2016. Seitsemän kummaa veljestä. Kertomuksia suomalaisen homoseksuaalisuuden historiasta. Helsinki: Gaudeamus.

Halperin, David M. 2000. How to Do the History of Male Homosexuality. GLQ: A Journal of Lesbian \& Gay Studies 6 (1), lk 87-124.

Halperin, David M. 2004. How to Do the History of Homosexuality. Chicago \& London: University of Chicago Press.

Hannoveri 1924 = Hannoveri veretöö. Uued üksikasjad. Sakala (1878-1940) 87, 31. juuli, $1 \mathrm{k} 2$.

Healey, Dan 2018. Russian Homophobia from Stalin to Sochi. London \& Oxford \& New York \& New Delhi \& Sidney: Bloomsbury Academic.

Hirschfeld, Magnus 1920. Die Homosexualität des Mannes und des Weibes : mit einem Namen-, Länder-, Orts- und Sachregister. Berlin: Marcus.

Homoseksualisti 1929 = Homoseksualisti vägivaldne surm. Sõdur surmas ebaloomuliku ettepaneku tegija. Sõjaringkonnakohtu 12-tunnine istung. Kaebealused 3 ja 1⁄1/2 a. vangiroodu. Päevaleht 46, 16. veebruar, lk 6.

Homoseksualistide 1927 = Homoseksualistide klubi Lätis. Kaja 269, 17. november, lk 7. Inimesed 1928 = Inimesed "kolmandamast soost". Rahvaleht nr 75, 28. juuni, lk 4. 
Istrati, Panait 1930. Sissejuhatus armastusgeograafiasse. Nõukogude Vene. Nool (Tartu) 52, 22. november, lk 9 .

Jõeäär, A[leksander] 1926. Avalik kiri pr. Helmi Mäelole. Päevaleht 344, 18. detsember, lk 4.

Jõeäär, A[leksander] (koost) 1929. Kriminaalseadustik. Lisadega ja sisujuhiga varustanud A. Jõeäär. Tallinn: Riigi Trükikoda.

J[ürgenstein], A[nton] 1925. Kirjandusest. Vilmar Adams: Suudlus lumme. Postimees 1, 2. jaanuar, lk 3 .

Kaks arstiteaduslist $1924=$ Sein. Kaks arstiteaduslist küsimust. Päevaleht 93, 5. aprill, lk 5 .

Kalkun, Andreas 2010a. Naiselikkus, mehelikkus ja seksuaalsus talupojakultuuris. Siin kasvab priskelt eesti neiu ja sirgub eesti mehele? Davidjants, Brigitta (koost). Kapiuksed valla. Arutlusi homo-, bi-ja transseksuaalsusest. Tallinn: Avatud Eesti Fond, MTÜ Eesti Gei Noored, lk 12-22.

Kalkun, Andreas 2010b. Work First and Love Will Follow. Division of Labor and Male Beauty in Estonian Folk Culture. Samma, Jaanus \& Paistik, Alo (toim). AAFAGC. Applied Art for a Gay Club (51-62). Tallinn, Paris.

Kalkun, Andreas 2016. Feodor Vanahundi ropud naljad. Erootiline imperatiiv, poeesia ja tabustatud seksuaalkäitumise viisid. Kästik, Helen \& Saar, Eva (toim). Tartu Ülikooli Lõuna-Eesti keele- ja kultuuriuuringute keskuse aastaraamat XV-XVI. Setumaa kogumik 7. Pühendusteos Paul Hagule. Tartu-Värska: Tartu Ülikooli Kirjastus, lk 118-137.

Kalkun, Andreas 2017. Talurahva seksuaalelu mõistatusi. Mü̈̈rileht (24-25) (https:// www.muurileht.ee/talurahva-seksuaalelu-moistatusi/ - 14. juuni 2018).

Kirjasaatjalt $1929=8$ kadunud poisikest. Varastab lapsi homoseksuaalsete ihade rahuldamiseks. Lõpuks tapab oma ohvri. Poisikeste rüvetaja ja tapja Riias. (Meie kirjasaatjalt traaditeel.) Esmaspäev. Piltidega nädalaleht 2, 14. jaanuar, lk 1.

Kiršenberg, dr 1935 = Dr. Kiršenbergi loeng: Felix Ormusson. Don-juan hingearsti prilli läbi. On Don-juanid täismehed? Film ja Elu: Huvitav shurnaalleht 47, 29. november, lk 2.

Kuidas mehest 1931 = Kuidas mehest sai naine. Sakala 32, 17. märts, lk 7 .

Kui mees 1933 = Kui mees tunnistatakse naiseks. Päevaleht 313, 16. november, lk 3.

Lasketiiru 1928 = Lasketiiru mõrtsukatöö selgunud. Kaja 145, 26. juuni, lk 3.

Liivrand, Harry 2007. Jutt Georg Otsa homoseksuaalsusest tuli kadedusest. Harry Liivrand küsitleb Garibaldi Kivisalu, Georg Otsa parimat sõpra, kes kummutab kuulujutud lavatähe homoseksuaalsusest - nende juttude põhjus oli lihtsalt kadedus. Eesti Ekspress, 20. detsember (http://ekspress.delfi.ee/areen/jutt-georg-otsa-homoseksuaalsusest-tulikadedusest?id=27673039 -1 . juuni 2018).

Lipša, Ineta 2016. Communication of non-normative sexuality in inter-war Latvia (1920s and 1930s). Vērdiṇš, Kārlis \& Ozoliṇš, Jānis (toim). Queer stories of Europe. Cambridge Scholars Publishing, lk 144-173.

Looduse 1930 = Looduse kõrvalhüpped. Siseorganite "libisemine". Südame asemel tühi koht. Esmaspäev 36, 8. september, lk 3. 
Luuleharrastaja 1933. Klaperjaht poeedile. Nool 5, 18. märts, lk 6.

Lätis leiti 1931 = Lätis leiti hermafrodiit kahe peaajuga. Virumaa Teataja 41, 14. aprill, lk 1 .

Maa 1929 = Maa, kus naised mehi vägistavad. Kaja 10, 12. jaanuar, lk 4.

Melanko, Valdemar 2012. Puistohomot. Raportti Helsingin 1960-luvun homokulttuurista. Helsinki: Suomalaisen Kirjallisuuden Seura.

Mets, Reimo 2010. Seadused ja homoseksuaalsus. Homoseksuaalide õigused Eestis. Davidjants, Brigitta (toim). Kapiuksed valla. Arutlusi homo-, bi-ja transseksuaalsusest. Tallinn: Eesti Gei Noored, lk 82-90.

Morris, Charles E. 2006. Archival Queer. Rhetoric \& Public Affairs 9 (1), lk 145-151.

Muñoz, José Esteban 1996. Ephemera as Evidence: Introductory Notes to Queer Acts. Women \& Performance. A Journal of Feminist Theory 8 (2), lk 5-16 (doi: 10.1080/07407709608571228).

Mäelo, Helmi 1926. Nõuame rohkem arvestamist rahva ja riigiga. Kas karistust suguvilja hävitamise eest ära jätta? Päevaleht 329, 3. detsember, lk 2.

Newton, Esther 2000. Margaret Mead Made Me Gay. Personal Essays, Public Ideas. Durham \& London: Duke University Press.

Prof. dr. med. 1929 = Prof. dr. med. Magnus Hirschfeld tuleb Tallinna. Päevaleht 118, 29. aprill, lk 8 .

Protens 1928. Homoseksualistid meil ja mujal. Komblus langeb, homoseksualism levineb. Uudisleht 70, 19. september, lk 5.

Ploompuu, Jakob 1920. Millal sotsialism maailmas maksma hakkab? Postimees 104, 21. aprill, lk 1; 108, 24. aprill, lk 3; 111, 28. aprill, lk 4.

Püssikuul 1928 = Püssikuul kõrvaldas halva asja. Joobnud mehe kallaletung sõdurile. Kaja 211, 9. september, lk 6.

Reinberg, K. 1937. Kontvõõrana Saksa Mihkli juures. Elamusi ja kohtamisi pärastsõjaaegsel Saksamaal. Vaba Maa 256, 6. november, lk 8.

Rohy, Valerie 2010. In the Queer Archive. Fun Home. GLQ: A Journal of Lesbian \& Gay Studies 16 (3), lk 341-361 (doi: 10.1215/10642684-2009-034).

Saarmann, K. \& Matto, K. 1937. Kriminaalseadustik. Kommenteeritud väljaanne. Tallinn: Autorite Kirjastus.

Samma, Jaanus \& Viola, Eugenio 2015. Not suitable for work. A chairman's tale. Berlin: Sternberg Press \& Tallinn: Center for Contemporary Arts.

S[chwalbe], J[ohannes] 1925. Veel kord "Suudlusest lumme", perversiteedist ja uusriimist. Postimees 11, 12. jaanuar, lk 3.

Sorainen, Antu 1996. Rikollisia sattumalta. Oikeustapauksia naisten keskinäisestä haureudesta 1950-luvun Itä-Suomesta. Rahikainen, Marjatta (toim). Matkoja moderniin. Lähikuvia suomalaisten elämästä. Historiallinen Arkisto - Historical Archives, Societas Historica Finlandiae 107. Helsinki: SHS, lk 187-212. 
Sorainen, Antu 1998. The power of confession: The role of criminal law and courtpractices in the production of knowledge concerning sexuality between women: Finland in the 1950s. Journal of Homosexuality, Special Double Issue, 35 (3/4): Scandinavian Homosexualities: Essays on Gay and Lesbian Studies. New York: The Haworth Press, lk 117-138 (doi: 10.1300/J082v35n03_05).

Szulc, Lukasz 2017. Transnational Homosexuals in Communist Poland: Cross-Border Flows in Gay and Lesbian Magazines. New York: Palgrave Macmillan.

Suguelu päevaküsimusi 1929 = Suguelu päevaküsimusi 1929. Päevaleht 118, 3. mai, lk 4.

Surmahoop 1928 = Surmahoop kaikaga. Noorsõdur tappis kõlvatu kallaletungija. Homoseksualisti laip lennuväe lasketiirul. Esmaspäev. Piltidega nädalaleht 26, 25. juuni, lk 1.

Triisberg, Airi 2017. Anna-Stina Treumundi praktika lesbi-, queer-ja feministliku poliitika kontekstis. Artel, Rael (koost). Anna-Stina Treumund. Tartu: Tartu Kunstimuuseum, lk 9-22.

Ward, Jane 2015. Not Gay: Sex between Straight White Men. New York University Press.

Veiser, Marja-Liisa 2006. Eesti kriminaalõiguse üldosa reform kahekümnendal sajandil võrdleva analüüsi peeglis. Tartu: Halo Kirjastus.

Veispak, Teet 1991. Homosexuality in Estonia in the 20th Century: Ideological and Juridical Aspects. Parikas, Udo \& Veispak, Teet (toim). Sexual Minorities and Society. The Changing Attitudes Toward Homosexuality in 20th Century Europe. Papers Presented to the International Conference in Tallinn May 28-30, 1990. Tallinn: Eesti Teaduste Akadeemia ajaloo instituut, $1 \mathrm{k}$ 115-121.

Võõra 1932 = Võõra lipu all. Eestlane palgasõdurina võõraleegionis. Esmaspäev. Piltidega nädalaleht 47,21 . november, $1 \mathrm{k} 5$.

\section{Summary}

\section{A history that never was? Traces of homosexual desire in three court cases}

\section{Andreas Kalkun}

Researcher, Estonian Folklore Archives, Estonian Literary Museum andreas.kalkun@folklore.ee

Keywords: homosexuality, Military District Court of the Republic of Estonia, queer history

The criminal code of the Republic of Estonia, in which homosexual acts between consenting adults were not considered to be a crime, was adopted in 1929 but came into force as late as at the beginning of 1935 . Before the adoption of the new criminal law, the criminal and correctional penal code of Imperial Russia was observed in the Republic of Estonia, and Article 995 of this code considered "pederasty" a crime. The article 
analyses three court cases of men on trial for homosexuality at the Military District Court of the Republic of Estonia in 1919, 1929, and 1931. In addition to the court cases, articles discussing homosexuality published in the newspapers of the period are used as sources to provide a context and discourse to frame the court files under discussion. I analyse specific texts related to punishment and correction, included in the court files, as potential sources in queer history research.

The majority of approaches to homosexuality published in the written press in the 1920 s and 1930s are misogynist and reproduce certain prejudices, notably emphasising, among other things, the spreadability of homosexuality in military institutions. At the same time, one can find newspaper texts which mediate ideas that were topical in Europe at the time about how homosexuality as a congenital condition should not be punishable by criminal law.

The court cases about "pederasty" emphatically focus on sex: the cases deal with criminalised sexual intercourse rather than, for example, explore romantic feelings or love. Owing to the focus on perversity and accusations, the cases are highly discriminatory and negative portrayals of the people. Writers of the transcripts have transformed the testimonies of the witnesses and the accused persons into odd court jargon and the accused themselves strive to impart as little information about them as possible. The accused may lie and be secretive or make desperate confessions but the information written in the transcripts is peculiarly biased and superficial.

The people accused in these court cases are of various backgrounds, and the gallery of characters is further widened by men who testified as witnesses and were sometimes part of a closer social circle of the accused. Manifestations of so-called homosexual desire in these stories also vary - there are consenting sexual intercourses, but also hierarchical, violent ones, or those the nature of which remains ambivalent in the sources. What really happened between the men prosecuted at the military district court remains largely hidden behind the veil of secrecy. The court transcripts are full of conflicting testimonies and generally speak only of physical bodies and convey the impressions of eye-witnesses. Emotions, sought after by queer histories, are explicitly scarce in the transcripts. Regardless of that, there are flashes of information popping up from time to time, casting most light on the lives and everyday practices of the accused or the nature of their homosexual desire. 